\title{
Effects of low pH and feeding on calcification rates of the cold-water coral Desmophyllum dianthus
}

\author{
Ariadna Martínez-Dios ${ }^{\text {Corresp., } 1}{ }^{\text {, Carles Pelejero }}{ }^{1,2}$, Àngel López-Sanz ${ }^{1}$, Robert Sherrell ${ }^{3,4}$, Stanley Ko ${ }^{5}$, Verena \\ Häussermannn $^{6,7}$, Günter Försterra ${ }^{6,7}$, Eva Calvo ${ }^{1}$ \\ 1 Institut de Ciències del Mar, CSIC, Barcelona, Catalonia, Espanya \\ 2 Institució Catalana de la Recerca i Estudis Avançats, Barcelona, Catalonia, Espanya \\ 3 Department of Marine and Coastal Sciences, Rutgers, The State University of New Jersey, New Brunswick, United States \\ 4 Department of Earth and Planetary Sciences, Rutgers, The State University of New Jersey, Piscataway, New Jersey, United States \\ 5 Department of Marine and Coastal Sciences, Rutgers, The State University of New Jersey, New Brunswick, New Jersey, United States \\ 6 Escuela de Ciencias del Mar / Facultad de Recursos Naturales, Pontificia Universidad Católica de Valparaíso, Valparaíso, Chile \\ 7 Huinay Scientific Field Station, Huinay, Chile \\ Corresponding Author: Ariadna Martínez-Dios \\ Email address: amartinez@icm.csic.es
}

Cold-Water Corals (CWCs), as most marine calcifiers, are especially threatened by Ocean Acidification (OA) and the decrease in the carbonate saturation state of seawater. The vulnerability of these organisms, however, also involves other global stressors like warming, deoxygenation or changes in sea surface productivity and, hence, food supply via the downward transport of organic matter to the deep ocean. This study examined the response of the CWC Desmophyllum dianthus to low $\mathrm{pH}$ under different feeding regimes through a long-term incubation experiment. For this, 152 polyps were incubated at $\mathrm{pH}$ 8.1, $7.8,7.5$ and 7.2 and two feeding regimes for 14 months. Mean calcification rates over the entire duration of the experiment ranged between -0.3 and $0.3 \mathrm{mg} \mathrm{CaCO}_{3} \mathrm{~g}^{-1} \mathrm{~d}^{-1}$. Polyps incubated at pH 7.2 were the most affected and $30 \%$ mortality was observed in this treatment. In addition, many of the surviving polyps at $\mathrm{pH} 7.2$ showed negative calcification rates indicating that, in the long term, CWCs may have difficulties to thrive in such aragonite undersaturated waters. The feeding regime had a significant effect on skeletal growth of corals, with high feeding frequency resulting in more positive and variable calcification rates. This was especially evident in corals reared at pH $7.5\left(\Omega_{A}=0.8\right)$ compared to the low frequency feeding treatment. Early life-stages, which are essential for the recruitment and maintenance of coral communities and their associated biodiversity, were revealed to be at highest risk. Overall, this study demonstrates the vulnerability of $D$. dianthus corals to low $\mathrm{pH}$ and low food availability. Future projected $\mathrm{pH}$ decreases and related changes in zooplankton communities could potentially compromise the viability of 


\title{
Effects of low pH and feeding on calcification rates of the cold-water coral Desmophyllum dianthus
}

\author{
Authors: Ariadna Martínez-Dios ${ }^{1}$, Carles Pelejero ${ }^{1,2}$, Àngel López-Sanz ${ }^{1}$, Robert M. Sherrell ${ }^{3,4}$, \\ Stanley $\mathrm{Ko}^{3}$, Vreni Häussermann ${ }^{5,6}$, Günter Försterra ${ }^{5,6}$ and Eva Calvo ${ }^{1}$ \\ ${ }^{1}$ Institut de Ciències del Mar, CSIC, Barcelona, Catalonia, Spain \\ 2 Institució Catalana de Recerca i Estudis Avançats, Barcelona, Catalonia, Spain \\ ${ }^{3}$ Department of Marine and Coastal Sciences, Rutgers The State University of New Jersey, \\ New Brunswick, NJ, USA \\ ${ }^{4}$ Department of Earth and Planetary Sciences, Rutgers The State University of New Jersey, \\ Piscataway, NJ, USA \\ ${ }^{5}$ Facultad de Recursos Naturales, Escuela de Ciencias del Mar, Pontificia Universidad Católica \\ de Valparaíso, Valparaíso, Chile \\ ${ }^{6}$ Huinay Scientific Field Station, Chile \\ Corresponding author: Ariadna Martínez-Dios amartinez@icm.csic.es
}

\section{Subjects: Climate Change, Marine Biology}

Keywords: Deep-sea corals, Ocean Acidification, Scleractinian corals, Coral feeding, Coral calcification, Global change, Carbonate saturation

\section{Abstract}

Cold-Water Corals (CWCs), as most marine calcifiers, are especially threatened by Ocean Acidification (OA) and the decrease in the carbonate saturation state of seawater. The vulnerability of these organisms, however, also involves other global stressors like warming, deoxygenation or changes in sea surface productivity and, hence, food supply via the downward transport of organic matter to the deep ocean. This study examined the response of the CWC Desmophyllum dianthus to low $\mathrm{pH}$ under different feeding regimes through a long-term incubation experiment. For this, 152 polyps were incubated at $\mathrm{pH} 8.1,7.8,7.5$ and 7.2 and two feeding regimes for 14 months. Mean calcification rates over the entire duration of the experiment ranged between -0.3 and $0.3 \mathrm{mg} \mathrm{CaCO} \mathrm{g} \mathrm{g}^{-1} \mathrm{~d}^{-1}$. Polyps incubated at $\mathrm{pH} 7.2$ were the most affected and $30 \%$ mortality was observed in this treatment. In addition, many of the surviving polyps at $\mathrm{pH} 7.2$ showed negative calcification rates indicating that, in the long term, CWCs may have difficulties to thrive in such aragonite undersaturated waters. The feeding regime had a significant effect on skeletal growth of corals, with high feeding frequency resulting in more positive and variable calcification rates. This was especially evident in corals reared at $\mathrm{pH} 7.5\left(\Omega_{A}=0.8\right)$ compared to the low frequency feeding treatment. Early life-stages, which are essential for the recruitment and maintenance of coral communities and their associated biodiversity, were revealed to be at highest risk. Overall, this study demonstrates the vulnerability of $D$. dianthus corals to low $\mathrm{pH}$ and low food availability. Future projected $\mathrm{pH}$ decreases and related changes in zooplankton communities could potentially compromise the viability of CWC populations. 


\section{Introduction}

Over the last two decades, and in parallel with the quantification of the oceanic absorption of anthropogenic $\mathrm{CO}_{2}$ (Gruber et al., 2019 and references therein), large efforts have been devoted to the study of past, present and future trends in ocean acidification (OA, e.g. Pelejero, Calvo and Hoegh-Guldberg, 2010; Gattusso et al., 2011; Bopp et al., 2013). Instrumental timeseries, which now cover up to three decades, corroborate the expected modern reduction in ocean pH (e.g. Bates et al., 2014; Kapsenberg et al., 2017) and it is estimated that surface pH in oceans, on average, has decreased $\sim 0.1$ units since pre-industrial times. This rate of change is about 100 times faster than during glacial to interglacial transitions (Pelejero, Calvo and Hoegh-Guldberg, 2010 and references therein). Further declines in seawater pH are projected in the future, accompanied by major changes in marine ecosystems and the organisms that constitute them (Hurd et al., 2018). Not surprisingly, both tropical and Cold-Water Corals (CWCs), as marine calcifiers, were the focus of most of the initial research, since the lowering in $\mathrm{pH}$ and the associated decrease in carbonate ion $\left(\mathrm{CO}_{3}{ }^{2-}\right)$ concentration, together with the shoaling of the aragonite $\left(\Omega_{\mathrm{A}}\right)$ saturation state horizon, could potentially compromise the calcification of their carbonate exoskeletons (Cohen and Holcomb, 2009). Cold-water corals comprise many species of ahermatypic corals (Scleractinia, Cnidaria) that generally inhabit high latitude and the deep ocean where specific hydrodynamic and food supply conditions favor coral growth, but that naturally exhibit relatively low values of $\mathrm{pH}$ and $\Omega_{\mathrm{A}}$ (e.g. Guinotte et al., 2006). The future shoaling of the aragonite saturation horizon projected for the global Ocean could soon threaten coral provinces in these basins by increasing their exposure to corrosive waters (Guinotte et al., 2006; Touratier and Goyet, 2009; Tittensor et al., 2010; Ciais et al., 2013; Hassoun et al., 2015; Perez et al., 2018).

Previous studies of tropical corals reported significant decreases in calcification with a lowering of $\mathrm{pH}$ (Chan and Connolly 2013 and references therein). Similarly, it was expected that OA could impact CWC communities as well (Guinotte et al., 2006), and perhaps even more severely, since they are characterized by extraordinary slow-growing and long-lived species that could be vulnerable to rapid and sustained changes in the chemistry of seawater (Roberts et al., 2006). Nevertheless, while there are nearly as many species of CWCs as their shallow tropical counterparts (Roberts and Cairns, 2014; Henry and Roberts, 2017), little is known about the biology of these enigmatic organisms, and even less about their response to OA. Indeed, culturing studies of CWCs with duration longer than one year have scarcely been performed so far, in part because the maintenance of these extremely slow-growing organisms in aquaria is technically challenging but, more importantly, because research on cold-water corals is a relatively young discipline. The use of Remotely Operated Vehicles (ROVs) has only recently been applied at the depths where these scleractinians often live, generally at a very high associated cost, especially if repeated access or the collection of a large number of individuals is required. This technology provided first glimpses into their biology and ecology and, since then, CWCs are known to contribute to the formation of complex reefs or coral mounds that support highly diverse marine life (Freiwald and Roberts, 2006; Henry and Roberts 2017).

Early studies on effects of OA on CWCs generally targeted key reef-building species such as Lophelia pertusa and Madrepora oculata and provided diverse and, in some cases, 
82

83

84

85

86

87

88

89

90

91

92

93

contradictory results. Indeed, many studies showed no significant response in calcification rate under high $\mathrm{pCO}_{2}$ (Maier et al., 2012, 2013; Form and Riebesell, 2012), but the conclusions were based on incubations shorter than in the present study. More recent literature shows, however, a decrease in net calcification of these species under acidified conditions (Maier et al., 2016; Gómez et al., 2018). The response of solitary species such as Desmophyllum dianthus has been less explored, but some of the few experiments exhibited signs of physiological stress (Carreiro-Silva et al., 2014), especially at certain life-stages (Movilla et al., 2014). Regarding other stressors in addition to OA, few studies have been carried out with CWCs, but several examined their response to low pH and food availability (Maier et al., 2016; Georgian et al., 2016; Büscher et al., 2017; Gómez et al., 2018). Being sessile suspension feeders, CWCs strongly depend on food resources from the water column, which are often scarce (Roberts, Wheeler and Freiwald, 2006), so food availability is very likely a key constraint that modulates the effects of environmental stressors such as OA in these species.

The present study aims to investigate the combined effects of acidification and food availability in the cold-water coral $D$. dianthus by means of a long-term culturing experiment of over 14 months. To the best of our knowledge, this is longer than any other incubation experiment performed so far with CWCs. We carried out the experiment over a wide range of $\mathrm{pH}$ (4 levels, 8.1, 7.8, 7.5, and 7.2, thus covering extreme scenarios that may be expected in the future, particularly in the deep Pacific Ocean), and under two feeding regimes. We hypothesized that corals incubated at high frequency feeding would benefit metabolically from the additional energy input, helping them to withstand aragonite undersaturation conditions, especially in the lowest $\mathrm{pH}$ treatments. The large sample size of our study (152 polyps) was only possible thanks to the unique conditions in Comau Fjord (Chilean Patagonia), where these corals form dense communities at unusually shallow depths (Forsterra and Haussermann, 2003; Cairns, Häussermann and Försterra, 2005), allowing the collection of a large number of corals of different sizes by means of SCUBA diving. This not only ensured the robustness of our results through replication but also provided the possibility of investigating the response of corals at different life stages.

\section{Materials and Methods}

\section{Studied species}

Desmophyllum dianthus (Esper, 1794) is a cosmopolitan species of solitary scleractinian coral (Cnidaria, Hexacorallia) living over a wide range of depths (from 7 to more than $4000 \mathrm{~m}$; Risk et al., 2002; Försterra and Häussermann, 2003). Most polyps have sizes of $5-10 \mathrm{~cm}$ in length and $1.5-3 \mathrm{~cm}$ in diameter, although larger specimens (up to $40 \mathrm{~cm}$ length) have often been found, especially attached to the underside of rocky overhangs (Cairns, Häussermann and Försterra, 2005). Although they form solitary polyps, $D$. dianthus can be found forming dense aggregations of pseudocolonies, especially on vertical rock faces or under overhanging ledges with the calyx facing downwards, presumably to prevent sedimentation, as occurs in Chilean Fjords (Försterra and Häussermann, 2003; Jantzen, et al., 2013). D. dianthus specimens are considered a generalist heterotrophic species: they feed on a wide range of zooplankton organisms and on a 
122

123

124

125

126

127

128

129

130

131

132

133

134

135

136

137

138

139

140

141

142

143

144

145

146

147

148

149

150

151

152

153

154

155

156

157

158

159

160

161

162

relatively steady supply of particulate organic carbon in the form of marine snow and perhaps also on dissolved organic matter (Naumann et al., 2011; Höfer et al., 2018).

\section{Specimen collection and experimental setup}

Approximately 200 live polyps of $D$. dianthus were collected manually by means of SCUBA diving in austral summer 2014 at two different sites of Comau Fjord: Punta Huinay and SWALL (Northern Chilean Patagonia; Fig. 1., at $\sim 20 \mathrm{~m}$ depth). The collection of animals for scientific purposes at the two sampling sites was approved by the sub-secretariat of fisheries and farming within the Chilean Ministry of Economy, Development \& Tourism (ref. 1760). The basaltic walls of the fjord where corals where collected, are bathed with seawater of relatively constant temperatures in the $10-12^{\circ} \mathrm{C}$ range and salinities of $31-33$ psu with a marked and stable lowsalinity surface layer, and $\mathrm{pH}$ values in the 7.4-8.2 range (Fig. 1., Försterra et al., 2005; Fillinger and Richter, 2013; Jantzen et al., 2013a).

The collected specimens were transported to Barcelona (CITES permit 14CL000006WS) in purpose-designed coolers and, once at the Experimental Aquarium Zone (ZAE) at the Institute of Marine Sciences (ICM), they were transferred to large refrigerated seawater containers installed inside a thermostatically controlled room $\left(10^{\circ} \mathrm{C}\right)$ with seawater maintained at this temperature. From the pool of polyps, 152 were carefully cleaned and weighed, and a small lump of epoxy putty was attached to the base of all specimens. In order to simulate their orientation in the natural envirorment of Comau Fjord, the epoxy bases of the corals were inserted into slots cut into a thick-walled silicone tube that was then positioned in the aquaria so that the corals were "tentacles down" and did not touch any surface or each other. Corals were then distributed in $2410 \mathrm{~L}$ aquaria comprising 3 replicate aquaria per treatment, with 6 to 7 individual polyps per aquarium, of randomized sizes ranges, and were left to acclimate to the experimental conditions for 9 months. During the acclimation process, corals were kept in natural Mediterranean seawater $(\mathrm{pH} \sim 8.1)$ and fed on weekday basis with a mixture of frozen zooplankton (fish food in blister packages, Ocean NutritionTM).

\section{Carbonate System manipulation}

After the acclimation period, we implemented a $\mathrm{pH}$-manipulative experimental system following the experimental design described in Movilla et al., (2012). A continuous flow of Mediterranean seawater obtained from an underwater intake at $10 \mathrm{~m}$ depth and $300 \mathrm{~m}$ offshore, 50 and $10 \mu \mathrm{m}$ filtered, was continuously supplied to four 150L tanks using a diaphragm pump (Iwaki IXC150TCR-TB1-E, $60 \mathrm{~L} / \mathrm{h}$ ) where $\mathrm{pH}$ was adjusted to values of $\sim 8.1, \sim 7.8, \sim 7.5$ and $\sim 7.2$ (on the total scale, $\mathrm{pH}_{\mathrm{T}}$; Fig. 2.) providing saturation state of aragonite $\left(\Omega_{\mathrm{A}}\right)$ of $\sim 2.7, \sim 1.3, \sim 0.8$ and $\sim 0.4$, respectively. Although these chosen $\mathrm{pH}$ and $\Omega_{\mathrm{A}}$ levels may seem rather extreme, projections using the most pessimistic emission scenario RCP8.5 (Representative Concentration Pathway 8.5 , where 8.5 is the radiative forcing, in $\mathrm{W} / \mathrm{m}^{2}$, expected by the year 2100 ; van Vuuren et al., 2011), reach values of $\Omega_{\mathrm{A}}$ below 0.5, particularly in the deep Pacific Ocean (Ciais et al., 2013). In the four large tanks, we either bubbled $\mathrm{CO}_{2}\left(99.9 \%\right.$ purity) or $\mathrm{CO}_{2}$-free air (using a homemade filter filled with soda lime, Sigma Aldrich) to reduce or increase $\mathrm{pH}$, respectively. Water from each large tank was transferred continuously to three replicates $10 \mathrm{~L}$ experimental aquaria for each feeding level, where the corals were maintained. Aquaria were placed in a thermo- 
163

164

165

166

167

168

169

170

171

172

173

174

175

176

177

178

179

180

181

182

183

184

185

186

187

188

189

190

191

192

193

194

195

196

197

198

199

200

201

202

203

204

regulated bath in order to prevent temperature oscillations and differences between aquaria. Water movement in the aquaria was provided by recirculation pumps and seawater renewal rate in these aquaria was 5 times per day. Additionally, all the aquaria were covered with a loosefitting methacrylate cap to reduce evaporation and minimize surface-air gas exchange, while allowing seawater to overflow the lip of the aquarium. During the first week of the acidification experiment, the $\mathrm{pH}$ was adjusted gradually (0.03 units per day) to the final selected values and maintained there for 433 days.

Seawater $\mathrm{pH}$ was monitored continuously by glass electrodes (LL Ecotrode plus-Metrohm) connected to a pH controller (Consort R305 and R362, Topac Inc., USA), which automatically opened and closed the solenoid valves of $\mathrm{CO}_{2}$ or $\mathrm{CO}_{2}$-free air when needed. To avoid drift in the $\mathrm{pH}$ measurements, glass electrodes were calibrated on a daily basis with a TRIS buffer, following standard procedures (SOP6a of Dickson, Sabine and Christian, 2007). Temperature and salinity in the aquaria were measured every 2-3 days using an YSI-30 M/10FT probe. In addition, analyses of alkalinity (TA) by potentiometric titration (Perez and Fraga, 1987; Pérez et al., 2000) and seawater $\mathrm{pH}$ by spectrophotometry (Clayton and Byrne, 1993) were carried out monthly. Four measurements (TA, pH, salinity and temperature) were used to calculate other variables of the $\mathrm{CO}_{2}$ system including dissolved inorganic carbon (DIC), carbonate ion concentration $\left(\mathrm{CO}_{3}{ }^{2-}\right)$, bicarbonate ion concentration $\left(\mathrm{HCO}_{3}{ }^{-}\right)$, partial pressure of $\mathrm{CO} 2\left(p \mathrm{CO}_{2}\right)$, aragonite saturation state $\left(\Omega_{\mathrm{A}}\right)$ and the mole fraction of $\mathrm{CO}_{2}$ in dry air $\left(\mathrm{XCO}_{2}\right)$, using the CO2SYS excel spreadsheet software (Pierrot, Lewis and Wallace, 2006) with dissociation constants for carbonate species determined by Mehrbach et al., (1973) and refit by Dickson and Millero, (1987). Chemical and physical conditions of both treatments during the experiment are shown in Table 1.

This experimental setup was developed in duplicate to allow for two feeding treatments at the same time (Fig. 2). In order to simulate as well as possible the natural field conditions and to compare with published literature, corals in this experiment were fed taking into account both the food type and the optimal prey size observed in natural habitats of $D$. dianthus (Höfer et al., 2018, Sánchez et al., 2011), in in trophic experiments with different CWCs (Tsounis et al., 2010; Purser et al., 2010; Naumann et al., 2011; Larsson, Lundälv and Van Oevelen, 2013) and our own expertise with previous experiments with this species (Movilla et al., 2014). Corals were fed with a mixture of frozen zooplankton (fish food in blister packages, Ocean NutritionTM) that included copepods of the genus Cyclops (1 cube), and small crustaceans such as Artemia salina (Crustacea, Sarsostraca) alternated with 1 cube of Mysis relicta (Crustacea, Eumalacostraca), all of them resuspended together in $40 \mathrm{~mL}$ of seawater. High frequency feeding (HF) corals were fed five days per week (Monday to Friday) while low frequency feeding (LF) corals were fed only twice per week (Monday and Thursday) using the same diet. The same volume $(3 \mathrm{~mL})$ of resuspended food was aliquotted to each aquarium using a graduated pipette. The average number of food items supplied to each aquarium at each feeding was assessed with repeated counts using an Olympus Stereomicroscope SZ60 under x1 magnification with a Bogorov chamber (Gannon, 1971). The average concentration of food particles in each $10 \mathrm{~L}$ aquarium after each food delivery was approximately 91 cyclops, 3 artemia and 2 mysis per liter (Table S1).

Peer) reviewing PDF | (2019:07:39495:1:1:NEW 12 Nov 2019) 


\section{Skeletal growth rates}

Skeletal growth of all coral polyps was assessed by means of the buoyant weight (BW) technique (Jokiel, Maragos and Franzisket, 1978; Davies, 1989), using a $0.1 \mathrm{mg}$ resolution balance (Mettler Toledo AB204 SFACT). An initial measurement of the BW was performed at the time when the organisms were distributed in the aquaria $(T=-1)$, a second one when the experiment started $(T=0)$, and subsequent weighing was conducted every 3 to 7 months throughout the experiment: T1 (119 days from T0), T2 (221 days from T0) and T3 (433 days from T0). During these measurements, temperature and salinity of seawater were continuously monitored using a YSI-30M probe. The net BW of the corals (calculated as the total coral weight minus the weight of the coral holder) was transformed to dry weight using the density of aragonite skeleton for $D$. dianthus species $\left(2.78 \mathrm{~g} / \mathrm{cm}^{3}\right.$; Movilla et al., 2014). Calcification rates were normalized to the skeletal weight at the beginning of the experiment (T0) and subsequently, to the beginning of each sampling period (T1-T3). Results are expressed as the increase in $\mathrm{mg} \mathrm{CaCO}_{3} \mathrm{~g}^{-1} \mathrm{~d}^{-1}$, which can be translated easily into \% mass increase $\mathrm{d}^{-1}$ for comparison with other published studies.

\section{Statistical analyses}

The underlying questions of our study, whether there exists a relationship between skeletal accretion and seawater $\mathrm{pH}$, and whether this relationship is modulated by the feeding regime, were evaluated statistically. For this analysis, we used calcification rate data for the 152 corals at the three discrete BW measurements. Moreover, since $D$. dianthus species are solitary corals that do not form colonies, all corals were treated as different individuals for statistical inference. Normality and homogeneity of variance were assessed graphically with $Q Q$ plots of residuals and Cook's distance plots to confirm analytical assumptions. Subsequently, a generalised least of squares (GLS) model was applied to untransformed data with the function gls (package nlme, Pinheiro et al., 2018) to evaluate the statistical significance of the experimental conditions $(\mathrm{pH}$, feeding frequency, incubation time and coral's initial size) on net calcification rate. Treatments were used as fixed effects while time and aquaria within each treatment were set as random effects in the statistical model with the formula: $\sim 1$ |time*aquaria, which adjusts for different variance per stratum. Differences among groups were examined post-hoc with the Ismeans function (package Ismeans, (Lenth, 2016). All the analyses were performed using the RStudio 1.1.383 software (2009-2017 RStudio, Inc). Data are reported as untransformed means and standard errors.

\section{Results}

\section{Carbonate system parameters}

The seawater $\mathrm{CO}_{2}$ system variables of all treatments were calculated from periodic paired spectrophotometric $\mathrm{pH}_{\mathrm{T}}$ and $\mathrm{TA}$ laboratory measurements (Table 1). For all treatments, temperature, salinity and alkalinity remained virtually constant for the duration of the experiment $\left(10.0 \pm 0.1{ }^{\circ} \mathrm{C}, 37.9 \pm 0.2\right.$ and $2539 \pm 4 \mu \mathrm{mol} / \mathrm{kg}$, respectively). The $\mathrm{pH}$ in all treatments was kept reasonably constant over the entire experiment, with values of $8.11 \pm 0.03,7.73 \pm 0.05$, 
244

245

246

247

248

249

250

251

252

253

254

255

256

257

258

259

260

261

262

263

264

265

266

267

268

269

270

271

272

273

274

275

276

277

278

279

280

281

282

$7.50 \pm 0.02$ and $7.24 \pm 0.02$. These levels led to $\Omega_{A}$ values of $2.74 \pm 0.13,1.31 \pm 0.13,0.80 \pm$ 0.04 and $0.45 \pm 0.02$, respectively.

Skeletal growth rates

Mean calcification rates during the entire experiment (T0-T3) ranged between -0.3 and $0.3 \mathrm{mg}$ $\mathrm{CaCO}_{3} \mathrm{~g}^{-1} \mathrm{~d}^{-1}$ (Fig. 3; Table 2). The explanatory variables to major observed differences in growth, evident in Figure 3, were pH (ANOVA F $=105.22, p$ value $=<0.0001, D F=436$ ) and feeding regime $($ ANOVA $F=4.088, p$ value $=0.0438, D F=436)($ Table 3$)$.

In general terms, as observed in Figure 3, HF corals showed higher calcification rates than LF corals as well as larger variability. Significant differences were also observed between feeding regimes, in all pH treatments. Calcification rates of corals at pH 8.1 were very similar to those at 7.8 and started to exhibit some detrimental effects at pH 7.5. Interestingly, the response of calcification was more acute in LF corals (Fig. 3). At pH 7.2, decreases in calcification were evident from the beginning of the experiment (Table 4). Indeed, during weight measurements, visual inspection of corals in this treatment revealed increased mucus production and retraction of the basal coenosarc tissue, resulting in the direct exposure of the skeleton to seawater.

These observations were statistically significant, and post-hoc analysis on the marginal means indeed revealed significant differences at the $95 \%$ confidence level on the calcification rate among pH treatments (Table 5), especially between the $\mathrm{pH} 7.2$ and 8.1 corals (TUKEY HSD tratio $=-15.736$, $p$-value $=<0.0001$ ). In fact, calcification was on average $17 \%$ and $30 \%$ lower in the 7.2 treatment in the HF and LF treatments, respectively (Fig. 3; Table 2). As mentioned above, boxplots in Figure 3 denote that corals incubated at $\mathrm{pH} 7.8$ barely differed from those exposed at pH 8.1 (TUKEY HSD t-ratio $=1.116, \mathrm{p}$-value $=0.68)($ Table 5$)$.

The effect of incubation time on growth was examined and found to be statistically significant (ANOVA F= 2.800, $p$-value $=0.0619$ ). As observed in Table 4, all treatments showed a slight reduction in calcification with time and, after 433 days of exposure, the average calcification was $11 \%$ lower compared to the beginning of the experiment.

When comparing the cumulative skeletal growth rate (in $\mathrm{mg} \mathrm{CaCO} 3 \mathrm{~g}-1 \mathrm{~d}-1$, normalized to the total polyp mass) for the whole experiment against the initial weight of each polyp at the beginning of the experiment (T0), there is a tendency of smaller corals to exhibit greater calcification rates than those with a higher initial weight (Fig. 4). Calcification rates of smaller corals were affected to a greater relative degree at the lowest seawater $\mathrm{pH}$. The survivorship in each treatment was $100 \%$ with the exception of the $\mathrm{pH} 7.2$ treatment aquaria, where $30 \%$ of corals died during the incubation regardless of the feeding. Moreover, as shown in Figure 5, negative calcification rates were detected for a substantial number of corals and visual inspection of the corals revealed the deterioration of the skeletons. This occurred in $31 \%$ of the total number of individuals, with those exposed to $\mathrm{pH} 7.2$ the worst affected; $~ 73 \%$ of the corals in this treatment showed clear signs of skeletal degradation such as more fragile, porous skeleton, some with small holes.

Discussion 
283

284

285

286

287

288

289

290

291

292

293

294

295

296

297

298

299

300

301

302

303

304

305

306

307

308

309

310

311

312

313

314

315

316

317

318

319

320

321

322

323

In this study, we report data from a 14 month OA culturing experiment with the CWC $D$. dianthus. In addition to $\mathrm{pH}$ manipulation, we have performed the experiment at two different frequency feeding regimes, to assess whether increased food supply could mitigate or partially offset the adverse effects of OA. With this experimental setup, we extract conclusions regarding some of the key conditions (seawater $\mathrm{pH}$ and feeding) for optimum growth in this CWC species at different life stages.

$\mathrm{pH}$ and aragonite saturation state ranges for optimum growth

Our results indicate a strong detrimental effect of sustained exposure to low $\mathrm{pH}$ ( 7.5 and below) and aragonite undersaturation $\left(\Omega_{\mathrm{A}}<1\right)$ on calcification rates of $D$. dianthus. The observed mortality and negative calcification rates (i.e. more dissolution than calcification), especially on polyps grown at $\mathrm{pH} 7.2$, suggests that, in the long term, CWCs will not be able to continue growing and maintaining their skeletons under these conditions. Our experiment suggests that, under $\Omega_{\mathrm{A}}$ values of around $0.8, D$. dianthus may not be able to calcify properly, depending on food intake rate, which in our experiment and others has not been quantified in absolute terms. Indeed, a threshold between positive and negative balance of calcification and dissolution was also found in the CWC M. oculata at $\Omega_{\mathrm{A}}$ of 0.92 (Maier et al., 2016).

Our evidence for a negative impact of OA on coral calcification agrees with a recent work with $L$. pertusa (Gómez et al., 2018), but contrasts with earlier studies based on shorter incubations, which were mostly undertaken at relatively higher $\mathrm{pH}$, rarely below $\sim 7.7$ and $\Omega_{\mathrm{A}} \sim 0.9$ (Table 6). For example, studies on $D$. dianthus and other CWCs such as L. pertusa and M. oculata (Maier et al., 2009, 2012; Form and Riebesell, 2012; Tittensor et al., 2013; Carreiro-Silva et al., 2014; Hennige et al., 2014; Movilla et al., 2014) revealed no effect of high $\mathrm{pCO}_{2}$ levels on net calcification. This is in agreement with our observations of non-significant differences in skeletal growth of corals incubated at $\mathrm{pH} 8.1$ and 7.8, but contrasts with our findings at $\mathrm{pH} 7.5$ and below. This apparent resistance at low levels of acidification has been attributed to the relatively low energetic requirements for calcification (Maier et al., 2016) and a particularly high degree of internal $\mathrm{pH}$ up-regulation in the calcifying fluid in these species (Anagnostou et al., 2012; McCulloch et al., 2012). In fact, this robustness and pH tolerance of CWCs is already evident from their natural habitat distribution. For example, D. dianthus corals, as a cosmopolitan species, have been found living over a wide range of $\mathrm{pH}$ levels in the Patagonian Fjords (8.1 to 7.4, Jantzen et al., 2013b; Fillinger and Richter, 2013) as well as in waters below the aragonite saturation horizon (Anagnostou et al., 2011; Thresher et al., 2011; Jantzen et al., 2013b). However, as mentioned above, $\mathrm{pH}$ and $\Omega_{\mathrm{A}}$ levels could potentially reach rather extreme low levels in the near future, in the range of those experimented within our study, particularly in the deep waters where CWCs develop. In the deep Pacific Ocean, for example, projections using the most pessimistic emission scenario RCP8.5 reach values of $\Omega_{\mathrm{A}}$ below 0.5 by the end of the century (Ciais et al., 2013), and in the North Atlantic Ocean, the aragonite saturation horizon is expected to shoal very quickly, rising on the order of 1000 to $1700 \mathrm{~m}$ in only three decades, exposing some of the largest and more diverse CWC reefs in the world to undersaturated seawater (Perez et al., 2018). It is at these more extreme levels of $\mathrm{pH}$ and $\Omega_{\mathrm{A}}$ that we found clear negative effects of OA on $D$. dianthus growth. 


\section{Effect of time on the expression of potential effects}

In a previous experiment undertaken by our group with $D$. dianthus and Dendrophyllia cornigera, of shorter duration (11 months), we observed that $D$. dianthus polyps managed to grow during the first stages of the experiment but net calcification decreased strongly after 6 months of exposure to acidified waters (Movilla et al., 2014). This previous study, although performed at only two $\mathrm{pH}$ levels (8.1 and 7.8), revealed an effect of time in the appearance of potential effects, prompting the need to undertake long (multiple months) experiments.

In the present experiment, performed at four $\mathrm{pH}$ levels, incubation time was statistically significant but we did not observe similar effects of time exposure (Table 3). During our pH 7.8 treatment, which was the lowest pH in the experiment of Movilla et al., (2014), and the pH at which they observed a lagged response, we did not observe a significant decrease in net calcification over the course of the entire experiment. This could be partly explained by the fact that seawater $\mathrm{pH}$ at natural location of the corals in this study is close to 7.8 (Jantzen et al., $2013 \mathrm{~b}$ ). At the two low pH treatments however (pHs of 7.5 and 7.2), the negative effects in coral growth were observed rather quickly, during the first 4 months, as shown by the buoyant weight measurements (Table 3). At the most extreme $\mathrm{pH}$ of 7.2 , retraction of the coenenchyme and dissolution of the base was also visually evident, already during the first months of the experiment.

The time lag observed by Movilla et al., (2014) until the effects of OA on calcification rates manifested, suggests that exposure time could be a key variable governing the calcification response of organisms to OA. In unfavourable low-pH conditions, CWCs may devote more energy to biomineralisation at the expense of other important metabolic functions. There are many studies pointing to physiological and metabolic responses of CWCs to aragonite undersaturation, including decreases in lipid content, skeletal density, respiration and food capture rates (Bramanti et al., 2013; Hennige et al., 2014; Movilla et al., 2014; Georgian et al., 2016, Gori et al., 2016), as well as changes in the expression of genes involved in calcification, cellular stress and immune defenses specifically in D. dianthus (Carreiro-Silva et al., 2014) and tropical corals (Vidal-Dupiol et al., 2013). All these different responses indicate that the negative effects of OA can occur at all organismal levels and appear at the very beginning of an exposure to OA. The effects on vital structural functions such as skeletal growth and its maintenance seem to become evident, however, at later stages, when other physiological processes have already been compromised.

As discussed by Movilla et al., (2014), it is also possible that, due to specific life processes, different periods or seasons are more susceptible to OA stress than others. For example, during reproductive stages, energy balance may be focused on gamete production, maturation and spawning rather than calcification. Very recently, a first insight has been obtained into the reproductive biology of $D$. dianthus, specifically for specimens of the Chilean Fjords, in the same region where the polyps for this experiment were collected (Feehan, Waller and Häussermann, 2019). In that study, a highly seasonal reproduction was reported, spawning at the end of austral winter and beginning gamete production in early austral spring. During our experiment, we did not find evidences of reproduction (although this was indeed observed after this 
experiment was completed, see below), so the energy expenditure related to this vital process may not have played a role, perhaps explaining the lack of time lag in the growth responses we observed.

\section{Modulating effect of feeding on OA stress}

Despite a number of studies focusing on the factors explaining the distribution and biology of CWCs, often determined by the availability of food resources, knowledge of the feeding ecology of CWCs is still very limited. Feeding rate and food availability have been suggested to modulate the effects of acidification on coral growth in tropical species (Comeau, Carpenter and Edmunds, 2013; Drenkard et al., 2018). For CWCs, only a few studies to date have attempted to investigate the combined effects of changing seawater $\mathrm{pH}$ and food availability on coral growth, specifically in $M$. oculata and $L$. pertusa, which are the most well-studied CWC species (Larsson, Lundälv and Van Oevelen, 2013; Maier et al., 2016; Büscher, Form and Riebesell, 2017).

Our first observation of the combined effects of feeding frequency with $\mathrm{pH}$ was that, as we expected, higher feeding frequency had a positive effect on net calcification rates and the overall performance of corals at all $\mathrm{pH}$ treatments (Fig. 3). At pH 8.1 and 7.8, LF corals grew less than HF corals in general, but the balance between calcification and dissolution was positive. In the particular case of $\mathrm{pH} \mathrm{7.5,} \mathrm{this} \mathrm{balance} \mathrm{was} \mathrm{clearly} \mathrm{positive} \mathrm{in} \mathrm{the} \mathrm{HF} \mathrm{conditions,}$ but remained close to zero in the LF treatments. In the HF treatment, the additional input of energy from feeding apparently allowed corals to maintain positive skeletal accretion inaragonite undersaturated conditions. This mitigating effect of $\mathrm{HF}$ on the response of CWCs to environmental stressors could partially explain the extraordinarily high densities of $D$. dianthus found in the highly productive waters of the Chilean Patagonia fjords, despite the low $\mathrm{pH}$ and aragonite undersaturation that characterizes these regions, particularly in deep areas (Jantzen, et al., 2013; Fillinger and Richter, 2013). At the more extreme values of $\mathrm{pH} \mathrm{7.2,} \mathrm{however,} \mathrm{corals}$ in our experiment were unable to compensate for the adverse effects of acidification regardless of the feeding regime. In both feeding regimes, the average growth was negative. Thus, even in regions with abundant food, the extreme cases of ocean acidification will have an important impact and may compromise these species.

Our results, revealing an apparent mitigation of OA effects in coral growth at $\mathrm{pH} 7.5$ (but not at $\mathrm{pH}$ 7.2) contrast with two recent studies based on M. oculata colonies (Maier et al., 2016) and $L$. pertusa (Büscher et al., 2017), where no mitigating effects of feeding were observed in calcification rates under acidified conditions. We speculate that, in the face of environmental pressures, differences exist in growth responses and survival strategies between threedimensional reef builders such as $M$. oculata and $L$. pertusa and solitary polyps like $D$. dianthus. Solitary polyps may have a larger degree of freedom in adapting their response, independent of their neighboring polyps.

Energy requirements for coral calcification have been discussed and constrained in a variety of physiological and mechanistic studies that have addressed the issue from multiple perspectives. Carbonic anhydrases (CA), for example, have been shown to play a crucial role in calcification, by catalyzing the interconversion of $\mathrm{CO}_{2}$ and bicarbonate ions, regulating the internal $\mathrm{pH}$ and 
406

407

408

409

410

411

412

413

414

415

416

417

418

419

420

421

422

423

424

425

426

427

428

429

430

431

432

433

434

435

436

437

438

439

440

441

442

443

444

445

446

447

448 the supply of ions for calcification (Zoccola et al., 2016 and references therein). Transcellular transport of $\mathrm{Ca}^{2+}$ through the $\mathrm{Ca}^{2+}$-ATPase channel is also key (e.g. Cohen and McConnaughey, 2003), as well as specific proteins at the site of initial calcification (e.g. Mass et al., 2014; Drenkard et al., 2018;). These, together with the need to pump protons out of the calcifying space and through the boundary layer (e.g. Jokiel, 2011) are, among other processes, examples of energy demanding mechanisms that may add to the clear differentiation observed in coral growth between HF and LF treatments in the present experiment.

A second observation from our experiment is the high variability in calcification rates of corals under the HF treatment as compared to the LF treatment, although this was less evident at the lowest $\mathrm{pH}$ (Fig. 3). Similar patterns of increased growth variability in response to a more abundant or better quality nutrition can also be seen in other studies with tropical corals (Osinga et al., 2011; Houlbréque et al., 2015; Conlan et al., 2017) and other CWCs (Büscher et al., 2017), although no emphasis or discussion on the reason for this was provided. According to Höfer et al., (2018), D. dianthus is a generalist species, feeding on a variety of zooplankton prey, which displays higher ingestion rates the higher the prey abundance, with no apparent limit. Therefore, we expect corals in the same treatment to feed as much as possible. The variability observed in HF treatment could be explained by the different morphological features of the polyps (size, calyx diameter, tentacle crown size), that would allow some corals to feed more efficiently than others. In addition, a food-replete environment may allow corals to reorganize energy allocation in order to increase inter-polyp competition for resources and reproductive success as observed in Crook et al., 2013. In this particular study, high food conditions also seemed to alleviate some of the stress associated with high $\mathrm{pCO}_{2}$ in the CWC solitary species Balanophyllia elegans. Better nutrition not only favoured calcification, but also increased the number of larvae released and reduced juvenile coral mortality by $5-15 \%$ (Crook et al., 2013). A possible role of energy expenditure for reproduction is supported by our observation that, after this experiment was completed, reproduction was observed in 8 polyps, and that this occurred mostly in $D$. dianthus polyps reared under HF (7 out of 8 ).

Despite these variable responses, CWCs are known to be well adapted to the extremely varying nutritious conditions of their natural habitat, as attested by the significant correlation between zooplankton food density and capture rates (Tsounis et al., 2010; Naumann et al., 2011; Larsson, Lundälv and Van Oevelen, 2013; Höfer et al., 2018). This correlation is related to a growing concern about projections for the future which, in general terms, indicate diminished primary productivity in many regions worldwide (Bopp et al., 2013; Fu, Randerson and Moore, 2016; Moore et al., 2018) with implications also for zooplankton dynamics, already negatively impacted by OA (Cripps, Lindeque and Flynn, 2014). In this situation, although the ecological and biogeochemical interactions among calcifying plankton, non-calcifying plankton and the resultant feedbacks on CWCs are complex and poorly understood (Hays, Richardson and Robinson, 2005), our work evidences the importance of food availability for the fate of $D$. dianthus communities under OA. For several specific areas, however, these pessimistic projections on primary production are not so clear or may even be reversed. In the Southern Ocean, for example, a region where CWCs are abundant (e.g. Thresher et al., 2011) there seems to be a much weaker increase in stratification, partly related to the poleward shift in westerly winds and associated increases in upwelling (Swart and Fyfe, 2012; Fu, Randerson

Peer) reviewing PDF | (2019:07:39495:1:1:NEW 12 Nov 2019) 
449

450

451

452

453

454

455

456

457

458

459

460

461

462

463

464

465

466

467

468

469

470

471

472

473

474

475

476

477

478

479

480

481

482

483

484

485

486

487

488

and Keith Moore, 2016), so the future may not be as bleak for CWCs in these regions, even with a predicted shoaling of the aragonite saturation horizon (Bostock et al., 2015).

\section{Ontogenic responses to low $\mathrm{pH}$}

Recent studies measuring vertical profiles of $\mathrm{pH}$ in the coelenteron of tropical corals show that OA may challenge calcification rates in adults with a deeper coelenteron cavity because of increased difficulty transporting $\mathrm{H}^{+}$out of the coelenteron and into the surrounding seawater (i.e., regulating internal $\mathrm{pH}$; Yuan et al., 2018). This contrasts with the results of the work presented here with CWCs, where smaller young polyps were more strongly affected as was also documented in many other acidification experiments (Comeau et al., 2014; Holcomb et al., 2014; Movilla et al., 2014, 2016; Maier et al., 2016). Indeed, for those juvenile D. dianthus reared at $\mathrm{pH} 7.2$, thriving may not have been possible if central portions of the polyp had been affected. Faster calcification, as described in benthic organisms, has generally been attributed to the greater energy allocation focused on skeletal growth (Cohen et al., 2009 and references therein) in order to overcome the strong selective pressure at this early life stages. Faster calcification, however, also requires more rapid transport of protons $\left(\mathrm{H}^{+}\right)$from the site of calcification (i.e. more energy) to maintain internal $\mathrm{pH}$ compared to slow growers (Comeau, Cornwall and McCulloch, 2017). Despite the importance of recruits and young adults recruits to the maintenance of coral communities, only few studies investigated the effects of OA in juvenile stages. According to Drenkard et al., (2018), juveniles of the zooxanthelate coral Favia fragum were unable to maintain calcification rates at $\mathrm{pH}$ 7.5-7.2. Since the allocation of energy is a key life history trait that sets the functional basis for maximizing the fitness of organisms, especially under resource limitation or physiological stress, more research is needed to investigate the effects of $\mathrm{OA}$ at key ontogenic stages crucial for the recruitment and sustainability of coral populations.

\section{Conclusions}

The findings of this research provide insight into the sensitivity of CWCs, and especially the solitary species $D$. dianthus, to the combination of ocean acidification and changes in food supply. Our data from this long-term incubation experiment show the vulnerability of $D$. dianthus coral populations to low $\mathrm{pH}$ conditions over long periods of time, starting at $\mathrm{pH} 7.5$ (and $\Omega_{\mathrm{A}}=$ 0.80 ), with a strong response at $\mathrm{pH} 7.2$ (and $\Omega_{\mathrm{A}}=0.45$ ) and young life stages. High frequency feeding had a positive impact on net calcification rates of polyps regardless of the seawater $\mathrm{pH}$. The increased food availability resulted in high inter-polyp, intra-condition variability of skeletal growth rates, as observed in nature, whereas low frequency feeding homogenized coral growth in all polyps, which probably focused their energy use on the vital process of building and maintaining their skeleton. Although the fate of CWC populations in coming centuries is still uncertain, it will be a result of the synergies and antagonisms generated by various environmental factors. In this study we show that seawater $\mathrm{pH}$ and food availability will likely play a key role, at least for $D$. dianthus. Additional long-term multi-factorial experimental approaches are needed to investigate the vulnerability and fate of CWCs in the future, especially at critical developmental stages, where corals are suspected to be at highest risk,

Peer) reviewing PDF | (2019:07:39495:1:1:NEW 12 Nov 2019) 
489

490

491

492

493

494

495

496

497

498

499

500

501

502

503

504

505

506

507

508

509

510

511

512

513

514

515

516

517

518

519

520

521

and which are essential for maintaining coral communities and their associated biodiversity under future $\mathrm{CO} 2$ scenarios.

\section{Acknowledgements}

We would like to thank the Huinay Station staff and especially to Ulrich Pörschmann for their help provided during our stay in Comau Fjord, including logistics, diving and laboratory assistance. We are also grateful to Juancho Movilla, Antonio Canepa and Rafel Coma for their recommendations and help with data treatment and statistics. We greatly appreciate the editor Erik Cordes and the two anonymous reviewers of this manuscript for their constructive comments. This is publication nr 170 of Huinay Scientific Field Station.

\section{Additional information and declarations}

\section{Funding}

This work was supported by projects GEODESMO (2014CL0020), funded by Consejo Superior de Investigaciones Científicas (CSIC), Fundación Endesa y Fundación San Ignacio de Huinay and SCORE (CGL-2015-68194-R) funded by the Spanish Ministry of Science, Innovation and Universities, which included a Formación de Personal Investigador (FPI) PhD grant to Ariadna Martínez Dios. The funders had no role in study design, data collection and analysis, decision to publish, or preparation of the manuscript.

\section{Competing Interests}

The authors declare there are no competing interests.

\section{Author Contributions}

Ariadna Martínez-Dios analyzed the data, wrote the paper, prepared figures and tables and reviewed drafts of the paper, and approved the final draft.

Carles Pelejero led the field trip to the Huinay Scientific Field Station in Chile to collect the $D$. dianthus corals, conceived, designed and supervised the experiment, contributed reagents/materials/analysis tools, wrote and reviewed the paper, approved the final draft.

Àngel López-Sanz participated in the field trip to the Huinay Scientific Field Station in Chile, collected the $D$. dianthus corals and participated in the set-up and maintenance of the experiment, approved the final draft.

Robert M. Sherrell, conceived and designed the experiment, contributed reagents/materials/analysis tools, revised drafts of the paper, approved the final draft.

Stanley Ko, contributed reagents/materials/analysis tools, reviewed drafts of the paper, approved the final draft. 
522 Vreni Häussermann helped with the logistics during the sampling at the Huinay Scientific Field

523 Station in Chile to collect the $D$. dianthus corals, contributed reagents/materials/analysis tools,

524 reviewed drafts of the paper, and approved the final draft.

525 Günter Försterra helped with the logistics during the sampling at the Huinay Scientific Field

526 Station in Chile to collect the $D$. dianthus corals, contributed reagents/materials/analysis tools,

527 reviewed drafts of the paper, and approved the final draft.

528 Eva Calvo conceived and designed the experiment, contributed reagents/materials/analysis 529 tools, reviewed drafts of the paper, approved the final draft.

\section{Field Study Permissions}

531 The collection of animals for scientific purposes at the two sampling sites was approved by the 532 sub-secretariat of fisheries and farming within the Chilean Ministry of Economy, Development \& 533 Tourism (ref.1760).

534 The following information was supplied relating to field study approvals (i.e., approving

535 body and any reference numbers):

536 CITES permit 14CL000006WS

537 Data Availability

538 The following information was supplied regarding data availability:

539 Raw data is available in the Supplemental Information.

\section{Supplemental Information}

541 Supplemental information for this article can be found online at:

\section{References}

543 Anagnostou, E., Sherrell, R. M., Gagnon, A., LaVigne, M., Field, M. P., McDonough, W. F. 544 (2011) 'Seawater nutrient and carbonate ion concetrations recorded as $\mathrm{P} / \mathrm{Ca}, \mathrm{Ba} / \mathrm{Ca}$ and $\mathrm{U} / \mathrm{Ca}$ 545 in the deep sea coral Desmophyllum dianthus', Geochimica et Cosmochimica Acta, 75(9), pp. 546 2529-2543. doi: 10.1016/j.gca.2011.02.019.

547 Anagnostou, E., Huang, K. F., You, C. F., Sikes, E. L., Sherrell, R. M. (2012) 'Evaluation of 548 boron isotope ratio as $\mathrm{pH}$ proxy in the deep sea coral Desmophyllum dianthus: Evidence of 549 physiological pH adjustment', Earth and Planetary Science Letters, 349-350, pp. 251-260. doi: 550 10.1016/j.epsl.2012.07.006.

551 Baillon, S., Hamel, J. F., Wareham, V. E., Mercier, A. (2012) 'Deep cold-water corals as 552 nurseries for fish larvae', Frontiers in Ecology and the Environment, 10(7), pp. 351-356. doi: $55310.1890 / 120022$. 
554 Bates, N. R., Astor, Y. M., Church, M. J., Currie, K., Dore, J. E., González-Dávila, M., Lorenzoni, 555 L., Muller-Kager, F., Olaffson, J., Santana-Casiano, J. M. (2014) 'A Time-Series View of 556 Changing Ocean Chemistry Due to Ocean Uptake of Anthropogenic CO2 and Ocean 557 Acidification', Oceanography, 27(1), pp. 126-141. doi: 10.5670/oceanog.2014.16.

558 Bopp, L., Resplandy, L., Orr, J. C., Doney, S. C., Dunne, J. P., Gehlen, M., Halloran, P., Heinze, 559 C., llyna, T., Séferian, R., Tjiputra, J., Vichi, M. (2013) 'Multiple stressors of ocean ecosystems 560 in the 21st century: Projections with CMIP5 models', Biogeosciences, 10(10), pp. 6225-6245. 561 doi: 10.5194/bg-10-6225-2013.

562 Bramanti, L., Movilla, J., Guron, M., Calvo, E., Gori, A., Dominguez-Carrió, C., Grinyó, J., 563 López-Sanz, A., Martinez-Quintana, A., Ziveri, P. (2013) 'Detrimental effects of ocean 564 acidification on the economically important Mediterranean red coral (Corallium rubrum)', Global 565 Change Biology, 19, 1897-1908. doi: 10.1111/gcb.12171.

566 Bostock, H. C., Tracey, D. M., Currie, K. I., Dunbar, G. B., Handler, M. R., Fletcher, S. E. M., 567 Smith, A. M., Williams, M. J. (2015) 'The carbonate mineralogy and distribution of habitat568 forming deep-sea corals in the southwest pacific region', Deep Sea Research Part I: 569 Oceanographic Research Papers, 100, pp. 88-104. 10.1016/j.dsr.2015.02.008 .

570 Büscher, J. V., Form, A. U., \& Riebesell, U. (2017) 'Interacctive effects of Ocean Acidification 571 and Warming on Growth, Fitness, and Survival of the Cold-Water Coral Lophelila pertusa under 572 different food availabilities, Frontiers in Marine Science, 4 (101), pp. 1-14. doi: 573 10.3389/fmars.2017.00101.

574 Cairns, S. D., Häussermann, V. and Försterra, G. (2005) 'A review of the Scleractinia (Cnidaria: 575 Anthozoa) of Chile, with the description of two new species', Zootaxa, 1018(1), pp. 15-46.

576 Carreiro-Silva, M., Cerqueira, T., Godinho, A., Caetano, M., Santos, R. S., Bettencourt, R. 577 (2014) 'Molecular mechanisms underlying the physiological responses of the cold-water coral 578 Desmophyllum dianthus to ocean acidification', Coral Reefs, 33(2), pp. 465-476. doi: 579 10.1007/s00338-014-1129-2.

580 Chan, N.C.S. and Connolly, S.R. (2013) 'Sensitivity of coral calcification to ocean acidification:a 581

582 Ciais, P., Sabine, C., Bala, G., Bopp, L., Brovkin, V., Canadell, J., Chhabra, A., Galloway, J., 583 Heimann, C., Jones, C., Le Quéré, C., Myneni, R. B., Piao, S., Thornton, P. (2013) 'IPCC 584 Climate Change 2013: The Physical Science Basis. Chapter 6: Carbon and Other 585 Biogeochemical Cycles', in Stocker, T. F., Qin, D., Plattner, G. K., Tignor, M., Allen, S. K., 586 Boschung, J., Nauels, A., Xia, Y., Bex, V.,Midgley, P. M. (eds) Climate Change 2013: The 587 Physical Science Basis. Contribution of Working Group I to the Fifth Assessment Report of the 588 Intergovernmental Panel on Climate Change, pp. 465-570, Cambridge: Cambridge University 589 Press. 
590 Clayton, T. D. and Byrne, R. H. (1993) 'Spectrophotometric seawater pH measurements: total 591 hydrogen ion concentration scale calibration of m-cresol purple and at-sea results', Deep Sea 592 Research Part I: Oceanographic Research Papers, 40(10), pp. 2115-2129.

593 Cohen, A. and Holcomb, M. (2009) 'Why Corals Care About Ocean Acidification: Uncovering 594 the Mechanism', Oceanography, 22(4), pp. 118-127. doi: 10.5670/oceanog.2009.102.

595 Cohen, A. L. and McConnaughey, T. A. (2003) 'Geochemical Perspectives on Coral 596 Mineralization', Reviews in Mineralogy and Geochemistry, 54(1), pp. 151-187. doi: 597 10.2113/0540151.

598 Comeau, S., Cornwal, C.E., and McCulloch, M. T. (2017) 'Decoupling between the response of 599 coral calcifying fluid $\mathrm{pH}$ and calcification to ocean acidification', Scientific reports, 7(1), pp. 1-10. 600 doi: 10.1038/s41598-017-08003-z.

601 Comeau, S., Edmunds, P. J., Spindel, N. B., Carpenter, R. C. (2014) 'Fast coral reef calcifiers 602 are more sensitive to ocean acidification in short-term laboratory incubations', Limnology and 603 Oceanography, 59(3), 1081-1091. doi: 10.4319/lo.2014.59.3.1081.

604 Comeau, S. and Carpenter, R. C. (2013) 'Effects of feeding and light intensity on the response 605 of the coral Porites rus to ocean acidification', Marine Biology, 160, 1127-1134. doi: 606 10.1007/s00227-012-2165-5.

607 Conlan, J., Conlan, J. A., Humphrey, C. A., Severati, A., \& Francis, D. S. (2017) 'Influence of 608 different feeding regimes on the survival, growth, and biochemical composition of Acropora 609 coral recruits', PLOS One, 12(11), pp. 1-20. Doi:10.1371/journal.pone.0188568.

610 Cripps, E., Lindeque, P., and Flynn, K. (2015) 'Have we been underestimating the effects of 611 ocean acidification in zooplankton?', Global Change Biology, 20, pp. 3377-3385. doi: $612 \quad 10.1111 / \mathrm{gcb} .12582$.

613 Crook, E. D., Cooper, H., Potts, D. C., Lambert, T., Paytan, A (2013) 'Impacts of food availability 614 and $\mathrm{pCO} 2$ on planulation, juvenile survival and calcification of the azooxanthellate scleractinian 615 coral Balanophyllia elegans', Biogeosciences, 10, pp. 7599-7608, doi: 10.5194/bg-10-75996162013.

617 Davies, S.P. (1989) 'Short-term growth measurements of corals using an accurate buoyant 618 weighing technique', Marine Biology, 101(3), pp. 389-395. doi: 10.1007/BF00428135.

619 Dickson, A. G. and Millero, F. J. (1987) 'A comparison of the equilibrium constants for the 620 dissociation of carbonic acid in seawater media', Deep Sea Research Part A. Oceanographic 621 Research Papers, 30(10), pp. 1733-1743.

622 Dickson, A. G., Sabine, C. L. and Christian, J. R. (2007) Guide to best practices for ocean $\mathrm{CO}_{2}$ 623 measurements. North Pacific Marine Science Organization.

624 Drenkard, E. J. et al. (2018) 'Juveniles of the Atlantic coral, Favia fragum (Esper, 1797) do not 625 invest energy to maintain calcification under ocean acidification', Journal of Experimental Marine 
626 Biology and Ecology. Elsevier, 507(September 2017), pp. 61-69. doi: 627 10.1016/j.jembe.2018.07.007.

628 Feehan, K. A., Waller, R. G. and Häussermann, V. (2019) 'Highly seasonal reproduction in 629 deep-water emergent Desmophyllum dianthus (Scleractinia: Caryophylliidae) from the Northern 630 Patagonian Fjords', Marine Biology. Springer Berlin Heidelberg, 166(52), pp. 1-13. doi: 631 10.1007/s00227-019-3495-3.

632 Fillinger, L. and Richter, C. (2013) ' Vertical and horizontal distribution of Desmophyllum 633 dianthus in Comau Fjord, Chile: a cold-water coral thriving at low pH ', PeerJ, 1, pp. 2-22 doi: 634 10.7717/peerj.194.

635 Form, A. U. and Riebesell, U. (2012) 'Acclimation to ocean acidification during long-term $\mathrm{CO}_{2}$ 636 exposure in the cold-water coral Lophelia pertusa', Global Change Biology, 18(3), pp. 843-853. 637 doi: 10.1111/j.1365-2486.2011.02583.x.

638 Försterra, G., Beuck, L., Häussermann, V., Freiwald, A. (2005) 'Shallow-water Desmophyllum 639 dianthus (Scleractinia) from Chile: characteristics of the biocoenoses, the bioeroding 640 community, heterotrophic interactions and (paleo)- bathymetric implications', in Freiwald, A. and 641 Roberts, J. M. (eds) Cold-water Corals and Ecosystems. Berlin: Springer-Verglang, pp. 937642977.

643 Forsterra, G. and Haussermann, V. (2003) 'First report on large scleractinian (Cnidaria: 644 Anthozoa) accumulations in cold-temperate shallow water of south Chilean fjords', Zoologische 645 Verhandelingen, pp. 117-128.

646 Freiwald, A. and Roberts, J. M. (2006) Cold-water corals and ecosystems. Springer Science \& 647 Business Media.

648 Fu, W., Randerson, J. T. and Keith Moore, J. (2016) 'Climate change impacts on net primary 649 production (NPP) and export production (EP) regulated by increasing stratification and 650 phytoplankton community structure in the CMIP5 models', Biogeosciences, 13(18), pp. 5151651 5170. doi: 10.5194/bg-13-5151-2016.

652 Gannon, J. E. . (1971) 'Two Counting Cells for the Enumeration of Zooplankton Micro653 Crustacea', Transactions of the American Microscopical Society, 90(4), pp. 486-490. doi: $654 \quad 10.2307 / 3225467$.

655 Gattuso, J.P.,Hansson, L. (Eds.) (2011) 'Ocean acidification’, Oxford University Press: Oxford. 656 pp. 326.

657 Georgian, S., Dupont, S., Kurman, M., Butler, A., Strömberg, S. M., Larsson, A. I., \& Cordes, E. 658 E. (2016) 'Biogeographic variability in the physiological response of cold-water coral Lophelia 659 pertusa to ocean acidification', Marine Ecology, 137(6), pp. 1345-1359. doi: $66010.1111 /$ maec.12373. 
661 Gómez, C. E., Wickes, L., Deegan, D., Etnoyer, P. J., Cordes, E. E. (2018) 'Growth and feeding 662 of deep-sea coral Lophelia pertusa from the California margin under simulated ocean 663 acidification conditions', PeerJ, 6, pp. 1-23. doi: 10.7717/peerj.5671.

664 Gori, A., Ferrier-Pagès, C., Hennige, S. J., Murray, F., Rottier, C., Wicks, L. C., \& Roberts, J. M. 665 (2016) 'Physiological response of the cold-water coral Desmopyllum dianthus to thermal stress 666 and ocean acidification', PeerJ, 4, pp.1-16. doi: 10.7717/peerj.1606.

667 Gruber, N., Clement, D., Carter, B. R., Feely, R. A., Van Heuven, S., Hoppema, M., Ishii, M., 668 Key, R. M., Kozyr, S., Lauvset, S. K., Lo Monaco, C., Mathis, J. T., Murata, A., Olsen, A., Perez, 669 F. F., Sabine, C. L., Tanhua, T., Wanninkhof, R. (2019) 'The oceanic sink for anthropogenic $\mathrm{CO}_{2}$ 670 from 1994 to 2007', Science, 363(6432), pp. 1193-1199. doi: 10.1126/science.aau5153.

671 Guinotte, J. J., M., Orr, J., Cairns, S., Freiwald, A., Morgan, L., George, R. (2006) 'Will 672 human-induced changes in seawater chemistry alter the distribution of deep-sea scleractinian 673 corals?', Frontiers in Ecology and the Environment, 4(3), pp. 141-146. doi: 10.1890/1540674 9295(2006)004[0141:WHCISC]2.0.CO;2.

675 Hassoun, A. E. R., Gemayel, E., Krasakopoulou, E., Goyet, C., Saab, M. A. A., Guglielmi, V., 676 Touratier, F., Falco, C. (2015) 'Acidification of the Mediterranean Sea from anthropogenic 677 carbon penetration', Deep-Sea Research Part I: Oceanographic Research Papers. Elsevier, 678 102, pp. 1-15. doi: 10.1016/j.dsr.2015.04.005.

679 Hays, G. C., Richardson, A.J., and Robinson, C. (2005) 'Climate change and marine plankton', 680 Trends in Ecology and Evolution, 20(6), pp. 337-344. doi: 10.1016/j.tree.2005.03.004.

681 Hennige, S. J., Wicks, L. C., Kamenos, N. A., Bakker, D. C., Findlay, H. S., Dumousseaud, C., 682 Roberts, J. M. (2014) 'Short-term metabolic and growth responses of the cold-water coral 683 Lophelia pertusa to ocean acidification', Deep-Sea Research Part II: Topical Studies in 684 Oceanography. Elsevier, 99, pp. 27-35. doi: 10.1016/j.dsr2.2013.07.005.

685 Henry, L. A. and Roberts, J. M. (2017) 'Global Biodiversity in Cold-Water Coral Reef 686 Ecosystems', in Rossi, S. (ed.) Marine Animal Forests: The Ecology of Benthic Biodiversity 687 Hotspots. Switzerland: Springer International Publishing, pp. 1-1366. doi: 10.1007/978-3-319688 21012-4.

689 Hurd, C.L., Lenton, A., Tilbrook, B., Boyd, P. W. (2018) 'Current understanding and challenges 690 for oceans in a higher-CO2 world', Nature Climate Change 8, pp. 686-694. doi: 0.1038/s41558691 018-0211-0.

692 Höfer, J., González, H. E., Laudien, J., Schmidt, G. M., Häussermann, V., Richter, C. (2018) 'All 693 you can eat: the functional response of the cold-water coral Desmophyllum dianthus feeding on 694 krill and copepods', PeerJ, 6, pp. 1-17. doi: 10.7717/peerj.5872.

695 Jantzen, C., Laudien, J., Sokol, S., Försterra, G., Häussermann, V., Kupprat, F., Richter, C. 696 (2013)a 'In situ short-term growth rates of a cold-water coral', Marine and Freshwater Research, 697 64(7), pp. 631-641. doi: 10.1071/mf12200. 
698

699

700

701

702

703

704

705

706

707

708

709

710

711

712

713

714

715

716

717

718

719

720

721

722

723

724

725

726

727

728

729

730

731

732

733

734
Jantzen, C., Häussermann, V., Försterra, G., Laudien, J., Ardelan, M., Maier, S., Richter, C. (2013)b 'Occurrence of a cold-water coral along natural pH gradients (Patagonia, Chile)', Marine Biology, 160(10), pp. 2597-2607. doi: 10.1007/s00227-013-2254-0.

Jokiel, P. L. (2011) 'Ocean Acidification and Control of Layer Limitation of Proton Flux', Bulletin of Marine Science, 87(3), pp. 639-657. doi: 10.5343/bms.2010.1107.

Jokiel, P., Maragos, J. and Franzisket, L. (1978) 'Coral growth: buoyant weight technique. In: Stoddart D.R., Johannes R.E. (eds) Coral reefs: research methods.', Coral reefs: research methods, (January 1978).

Kapsenberg, L., Alliouane, S., Gazeau, F., Mousseau, L., Gattuso, J. P. (2017) 'Coastal ocean acidification and increasing total alkalinity in the northwestern Mediterranean Sea', Ocean Science, 13(3), pp. 411-426. doi: 10.5194/os-13-411-2017.

Larsson, A. I., Lundälv and van Oevelen, D. (2013) 'Skeletal growth, respiration rate, and fatty acid composition in the cold-water coral Lophelia pertusa under varying food conditions', Marine Ecology Progress Series, 483, pp. 169-184, doi: 10.3354/meps10284.

Lenth, R. V. (2016) 'Least-Squares Means: The R Package Ismeans', Journal of Statistical Software, 69(1), pp. 1-33. doi: 10.18637/jss.v069.i01.

Lunden, J. J., McNicholl, C. G., Sears, C. R., Morrison, C. L., Cordes, E. E. (2014) 'Acute survivorship of the deep-sea coral Lophelia pertusa from Gulf of Mexico under acidification, warming and deoxygenation', Frontiers in Marine Science, 1(78), pp. 1-12, doi: 10.3389/fmars.2014.00078.

Maier, C., Hegeman, J., Weinbauer, M. G., Gattuso, J. P. (2009) 'Calcification of the cold-water coral Lophelia pertusa under ambient and reduced pH', Biogeosiences, 6(1671), pp. 16711680. doi: 10.1109/aero.1999.792098.

Maier, C., Watremez, P., Taviani, M., Weinbauer, M. G., Gattuso, J. P. (2012) 'Calcification rates and the effect of ocean acidification on Mediterranean cold-water corals', Proceedings of the Royal Society B: Biological Sciences, 279(1734), pp. 1716-1723. doi: 10.1098/rspb.2011.1763.

Maier, C., Schubert, A., Sànchez, M. M. B., Weinbauer, M. G., Watremez, P., Gattuso, J. P. (2013) 'End of the Century $\mathrm{pCO}_{2}$ Levels Do Not Impact Calcification in Mediterranean ColdWater Corals', PLoS ONE, 8(4), e62655. doi: 10.1371/journal.pone.0062655.

Maier, C., Popp, P., Sollfrank, N., Weinbauer, M. G., Wild, C., Gattuso, J. P. (2016) 'Effects of elevated $\mathrm{pCO}_{2}$ and feeding on net calcification and energy budget of the Mediterranean coldwater coral Madrepora oculata', The Journal of Experimental Biology, 219(20), pp. 3208-3217. doi: 10.1242/jeb.127159.

Mass, T., Drake, J. L., Peters, E. C., Jiang, W., Falkowski, P. G. (2014) 'Immunolocalization of skeletal matrix proteins in tissue and mineral of the coral Stylophora pistillata', Proceedings of the National Academy of Sciences, 111(35), pp. 12728-12733. doi: 10.1073/pnas.1408621111.

Peer) reviewing PDF | (2019:07:39495:1:1:NEW 12 Nov 2019) 
735

736

737

738

739

740

741

742

743

744

745

746

747

748

749

750

751

752

753

754

755

756

757

758

759

760

761

762

763

764

765

766

767

768

769

Mehrbach, C., Culberson, C. H., Hawley, J. E., Pytkowicx, R. M. (1973) 'Measurement of the apparent dissociation constants of carbonic acid in seawater at atmospheric pressure', Limnology and Oceanography, 18(6), pp. 897-907.

Moore, J. K., Fu, W., Primeau, F., Britten, G. L., Lindsay, K., Long, M., Doney, S. C., Mahowald, N., Hoffman, F., Randerson, J. T. (2018) 'Sustained climate warming drives declining marine biological productivity', Science, 359(6380), pp. 1139-1143. doi: 10.1126/science.aao6379.

Movilla, J., Calvo, E., Pelejero, C., Coma, R., Serrano, E., Fernández-Vallejo, P., Ribes, M. (2012) 'Calcification reduction and recovery in native and non-native Mediterranean corals in response to ocean acidification', Journal of Experimental Marine Biology and Ecology, 438, pp. 144-153. doi: 10.1016/j.jembe.2012.09.014.

Movilla, J., Gori, A., Calvo, E., Orejas, C., López-Sanz, À., Grinyó, J., Domínguez-Carrió, C., Pelejero, C. (2014) 'Differential response of two Mediterranean cold-water coral species to ocean acidification', Coral Reefs, 33(3), pp. 675-686. doi: 10.1007/s00338-014-1159-9.

Naumann, M. S., Orejas, C., Wild, C., \& Ferrier-Pagès, C. (2011) 'First evidence for zooplankton feeding sustaining key physiological processes in a scleractinian cold-water coral', Journal of Experimental Biology, 214(21), pp. 3570-3576. doi: 10.1242/jeb.061390.

Pelejero, C., Calvo, E. and Hoegh-Guldberg, O. (2010) 'Paleo-perspectives on ocean acidification', Trends in Ecology and Evolution. Elsevier Ltd, 25(6), pp. 332-344. doi: 10.1016/j.tree.2010.02.002.

Perez, F. F., Fontela, M., García-lbáñez, M. I., Mercier, H., Velo, A., Lherminier, P., Zunino, P., de la Paz, M., Alonso-Pérez, F., Guallart, E.F., Padin, X. A. (2018) 'Meridional overturning circulation conveys fast acidification to the deep Atlantic Ocean', Nature. Nature Publishing Group, 554(7693), pp. 515-518. doi: 10.1038/nature25493.

Perez, F. F., Ríos, A. F., Rellán, T., Álvarez, M. (2000) 'Improvements in a fast potentiometric seawater alkalinity determination', Ciencias Marinas, 26(3), pp. 463-478.

Perez, F. F. and Fraga, F. (1987) 'A precise and rapid analytical procedure for alkalinity determination', Marine Chemistry. Elsevier, 21(2), pp. 169-182.

Pierrot, D. E., Lewis, D. and Wallace, W. R. (2006) 'MS Excel Program Developed for CO2 System Calculations'. Oak Ridge National Laboratory.

Purser, A., Larsson, A. I., Thomsen, L., van Oevelen, D. (2010) 'Influence of flow velocity and food concentratio on Lophelia pertusa (Scleractinia) zooplankton capture rates', Journal of Experimental Marine Biology and Ecology, 395, pp. 55-62, doi: 10.1016/j.jembe.2010.08.013.

Risk, M. J., Heikoop, J. M., Snow, M. G., \& Beukens, R. (2002) 'Lifespans and growth patterns of two deep-sea corals: Primnoa resedaeformis and Desmophyllum cristagalli', Hydrobiologia, 471, pp. 125-131. doi: 10.1023/A:1016557405185.

Peer) reviewing PDF | (2019:07:39495:1:1:NEW 12 Nov 2019) 
770 Roberts, J. M. and Cairns, S. D. (2014) 'Cold-water corals in a changing ocean', Current

771 Opinion in Environmental Sustainability. Elsevier B.V., 7, pp. 118-126. doi:

772 10.1016/j.cosust.2014.01.004.

773 Roberts, J. M., Wheeler, A. J. and Freiwald, A. (2006) 'Reefs of the Deep: The Biology and

774 Geology of Cold-Water Coral Ecosystems', Science, 312 (April), pp. 543-547. doi:

775 10.1126/science.1119861.

776 Sánchez, N., González, H.E., Iriarte, J.L. (2011) 'Trophic interactions of pelagic crustaceans in 777 Comau Djord (Chile): their role in food web structure', Journal of Plankton Research, 33(8), pp.

778 1212-1229. doi:10.1093/plankt/fbr022.

779 Swart, N. C. and Fyfe, J. C. (2012) 'Observed and simulated changes in the Southern 780 Hemisphere surface westerly wind-stress', Geophysical Research Letters, 39(16), pp. 6-11. doi: 781 10.1029/2012GL052810.

782 Thresher, R. E., Adkins, J., Fallon, S. J., Gowlett-Holmes, K., Althaus, F., Williams, A. (2011) 783 'Extraordinarily high biomass benthic community on Southern Ocean seamounts', Scientific 784 Reports, 1, pp. 3-7. doi: 10.1038/srep00119.

785

786

787

788

789

790

791

792

793

794

795

796

797

798

799

800

801

802

803

804

805

Tittensor, D. P. Baco, A. R., Hall-Spencer, J. M., Orr, J. C., Rogers, A. D. (2010) 'Seamounts as refugia from ocean acidification for cold-water stony corals', Marine Ecology, 31(SUPPL. 1), pp. 212-225. doi: 10.1111/j.1439-0485.2010.00393.x.

Touratier, F. and Goyet, C. (2009) 'Decadal evolution of anthropogenic $\mathrm{CO}_{2}$ in the northwestern Mediterranean Sea from the mid-1990s to the mid-2000s', Deep-Sea Research Part I: Oceanographic Research Papers, 56(10), pp. 1708-1716. doi: 10.1016/j.dsr.2009.05.015.

Tsounis, G., Orejas, C., Reynaud, S., Gili, J. M., Allemand, D., Ferrier-Pagès, C. (2010) 'Preycapture rates in four Mediterranean cold water corals', Marine Ecology Progress Series, 398, pp. 149-155, doi: 10.3354/meps08312.

van Vuuren, D. P. Edmonds, J., Kainuma, M., Riahi, K., Thomson, A., Hibbard, K., Hurtt, G.C., Kram, T., Krey, V., Lamarque, J .F., Masui, T., Meinshausen, M., Nakicenovic, N., Smith, S.J., Rose, S. K. (2011) 'The representative concentration pathways: An overview', Climatic Change, 109(1), pp. 5-31. doi: 10.1007/s10584-011-0148-z.

Vidal-Dupiol, J., Zoccola, D., Tambutté, E., Grunau, C., Cosseau, C., Smith, K. M., Freitag, M. Dheilly, N. M., Allemand, D., Tambutté, S.(2013) 'Genes related to ion-transport and energy production are upregulated in response to $\mathrm{CO}_{2}$-driven $\mathrm{pH}$ decrease in Corals: New insights from transcriptome analysis', PLoS ONE, 8(3), e58652. doi:10.1371/journal.pone.0058652.

Yuan, X., Cai, W., Meile, C., Hopkinson, B.M., Ding, Q., Schoeph, V., Warner, M. E., Hoadley, K. D., Chen, B., Liu, S., Huang, H., Ye, Y., Grottoli, A.G.(2018) 'Quantitative interpretation of vertical profiles of calcium and pH in the coral coelenteron', Marine Chemistry, 204, pp. 62-69. doi: 10.1016/j.marchem.2018.06.001 
806 Zoccola, D., Innocenti, A., Bertucci, A., Tambutté, E., Supuran, C. T., Tambutté, S. (2016) 'Coral

807 carbonic anhydrases: Regulation by ocean acidification', Marine Drugs, 14(109), pp: 1-11. doi: 808 10.3390/md14060109. 


\title{
Figure 1
}

\section{Sampling locations in the Comau Fjord, Chilean Patagonia and depth profiles of water column properties.}

\begin{abstract}
(A) All polyps used in the experiment were sampled at the sites SWALL and Punta Huinay. B) and C) Geographical context. D) and E) show depth profiles temperature, $\mathrm{pH}$ (total scale) and alkalinity $(\mu \mathrm{Eq} / \mathrm{kg}$ ) close to collection sites (Jantzen et al., 2013; see D and E in the map) indicating that conditions at the collection depth $(\sim 20 \mathrm{~m})$ agree with conditions set in the experiment regarding temperature and $\mathrm{pH}(\mathrm{T} \underline{\mathrm{o}}=$ $11^{\circ} \mathrm{C} ; \mathrm{pH}=8$, total scale). There was, however, a significant difference in alkalinity, fundamentally due the difference in salinity between the Comau Fjord and Mediterranean water. Nevertheless, all polyps adapted rapidly to the new environmental conditions, actively opening their tentacles as in the field.
\end{abstract}


A

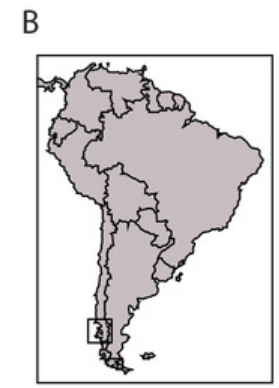

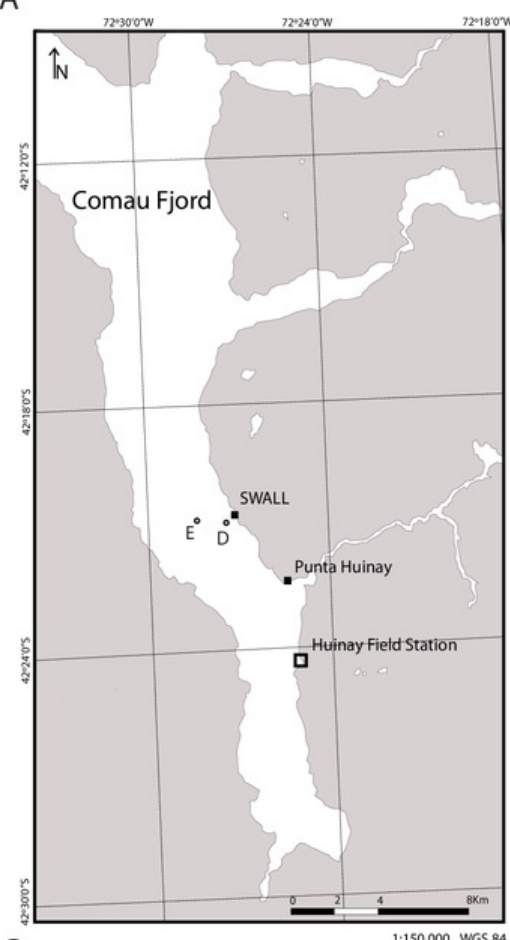

C

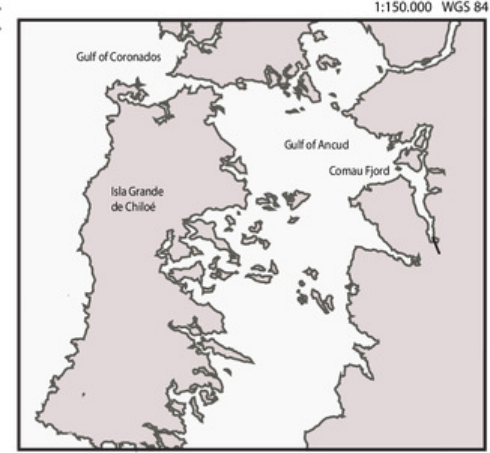

D
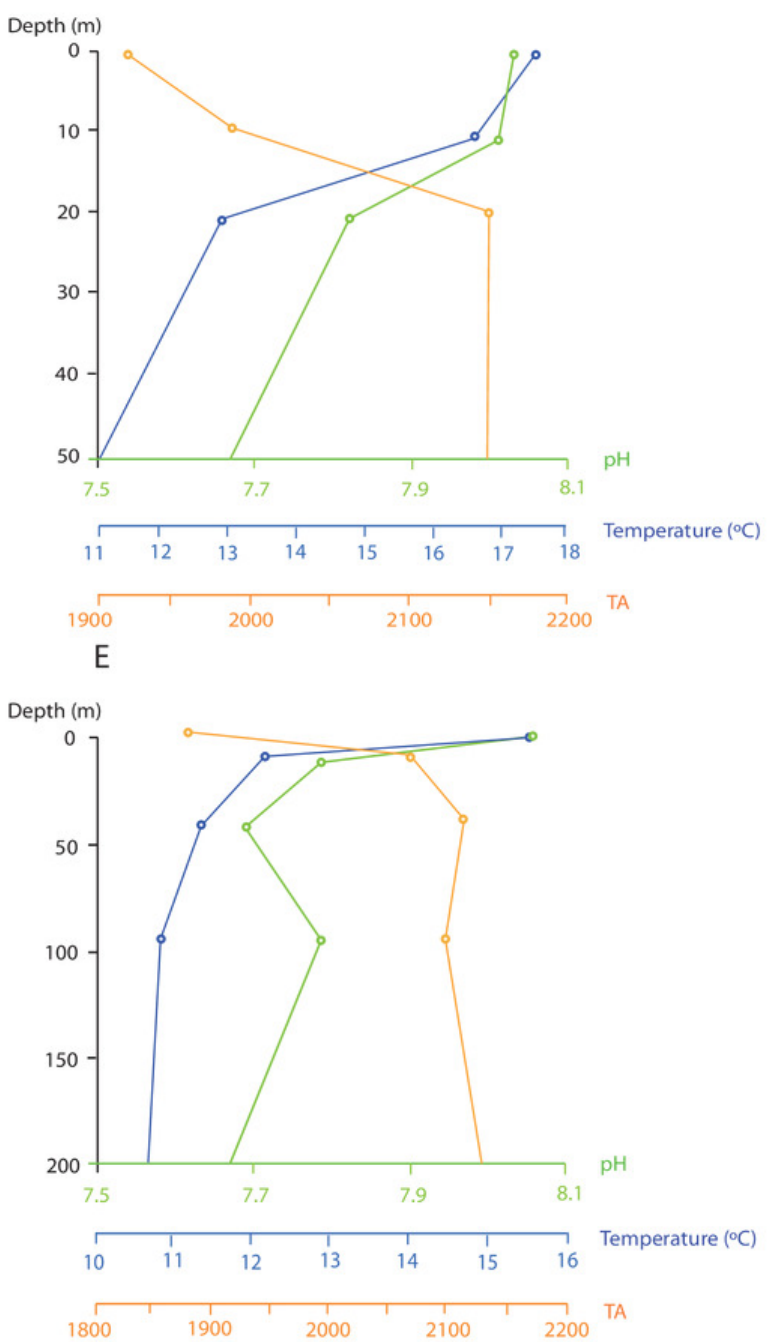


\section{Figure 2}

Experimental setup.

The experiment was performed in a thermostatically controlled room at $10^{\circ} \mathrm{C}$. The aquaria were maintained with a continuous flow of filtered (50 and $10 \mu \mathrm{m}$ ) Mediterranean seawater.

The $\mathrm{pH}$ was adjusted at the four head tanks with glass electrodes connected to $\mathrm{pH}$ controllers which automatically opened and closed solenoid valves of $\mathrm{CO}_{2}$ or $\mathrm{CO}_{2}$-free air as needed. Water in all $10 \mathrm{~L}$ aquaria overflowed to the large temperature baths, each of which had a water outlet (not shown). 


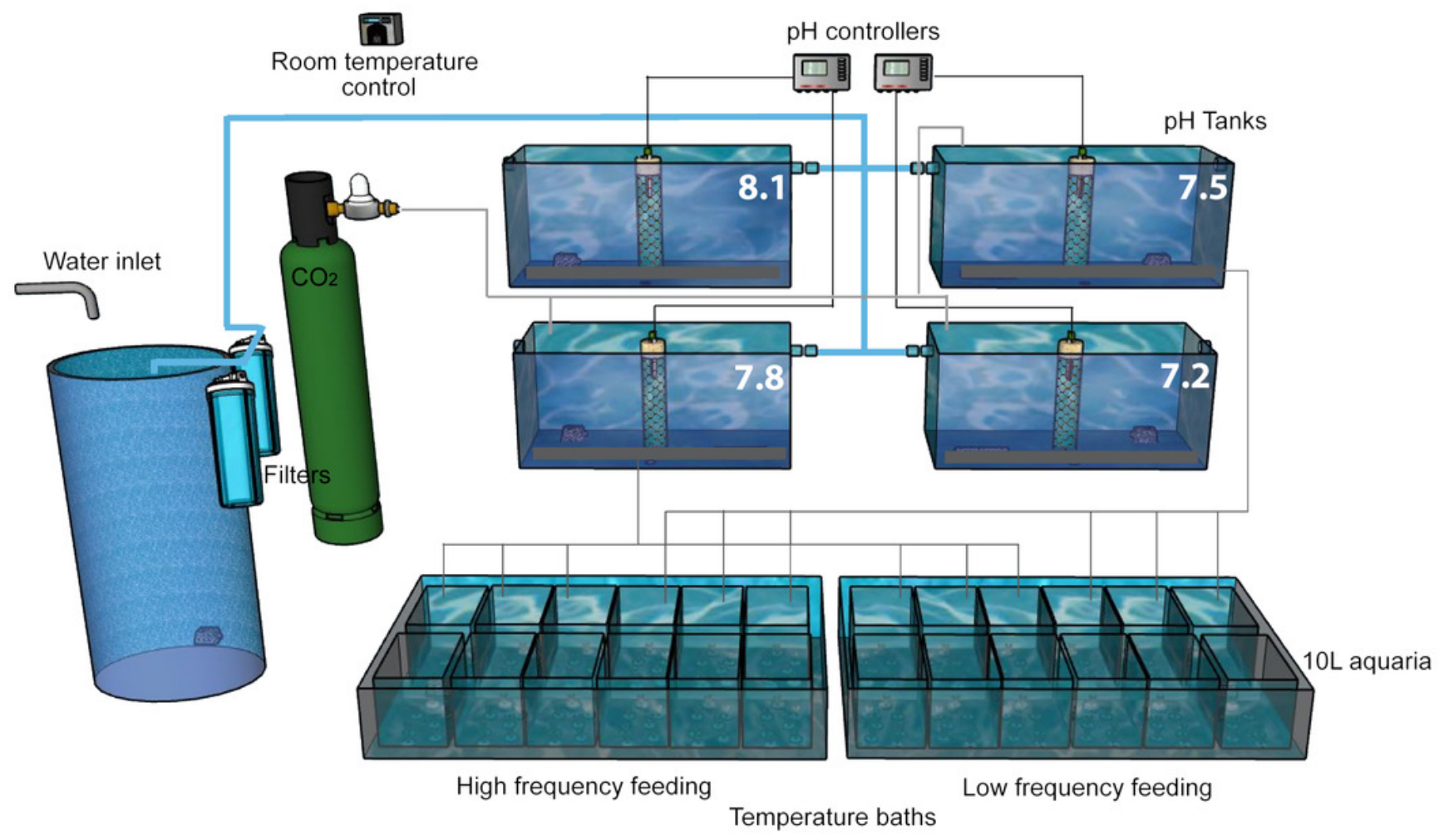




\section{Figure 3}

Box-and-whisker plots of skeletal growth rates of $D$. dianthus specimens during the whole experiment (433 days of incubation) at the four $\mathrm{pH}$ levels and two frequency feeding treatments.

Boxes delimit the first and third quartiles, with a horizontal line at the median, and whiskers represent the $10^{\text {th }}$ and $90^{\text {th }}$ percentiles. Outliers are represented by empty circles. The total number of polyps was 152 . 


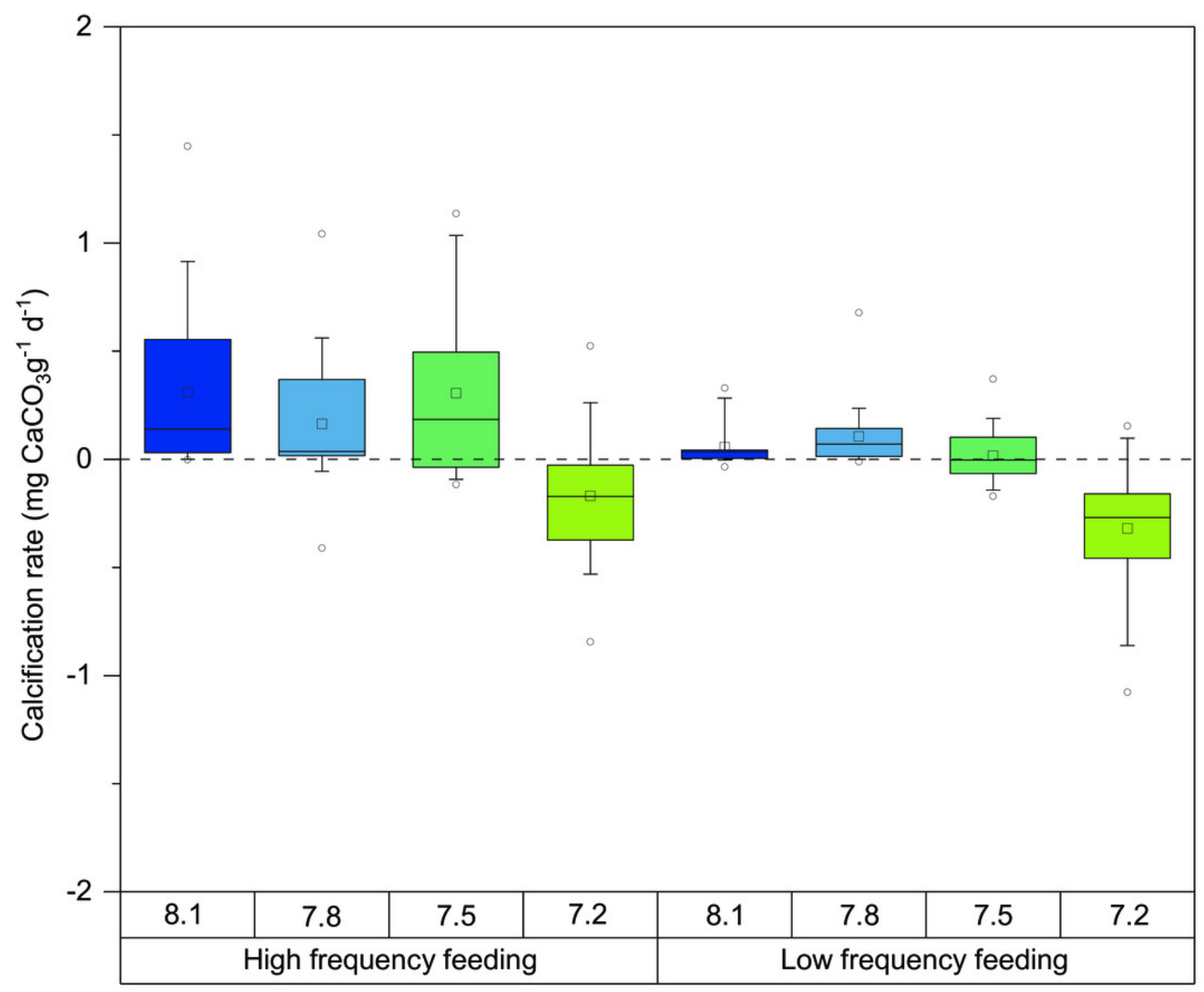


Figure 4

Scatter plot of the initial weight of the polyps and their calcification rate computed for the total duration of the experiment (433 days).

Note the color code corresponding to the different $\mathrm{pH}$ treatments.

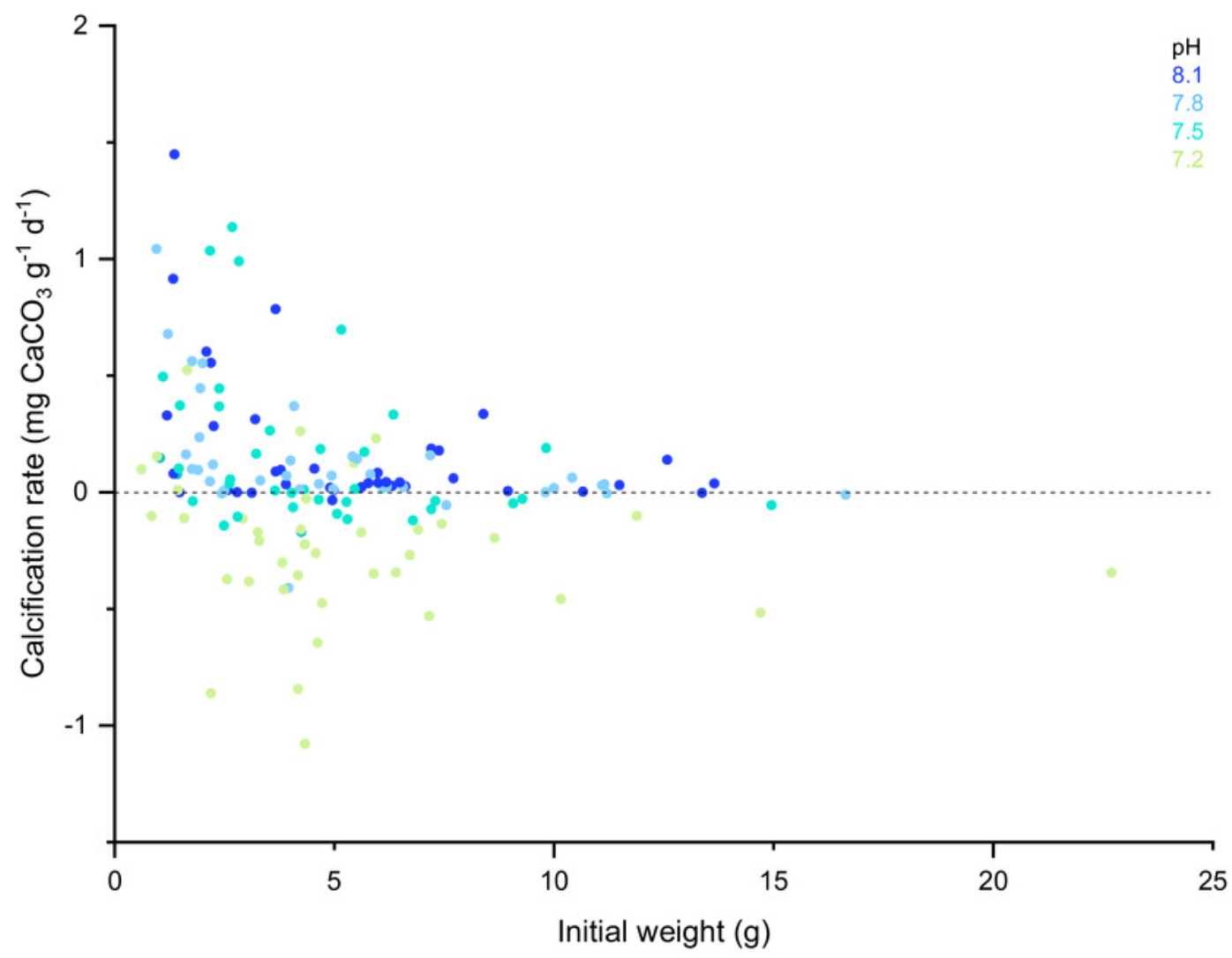


Figure 5

Histogram of the number of corals that exhibited negative calcification rates in each treatment.

The total number of polyps was 152 , and the total number of those that exhibited negative calcification was 48. 


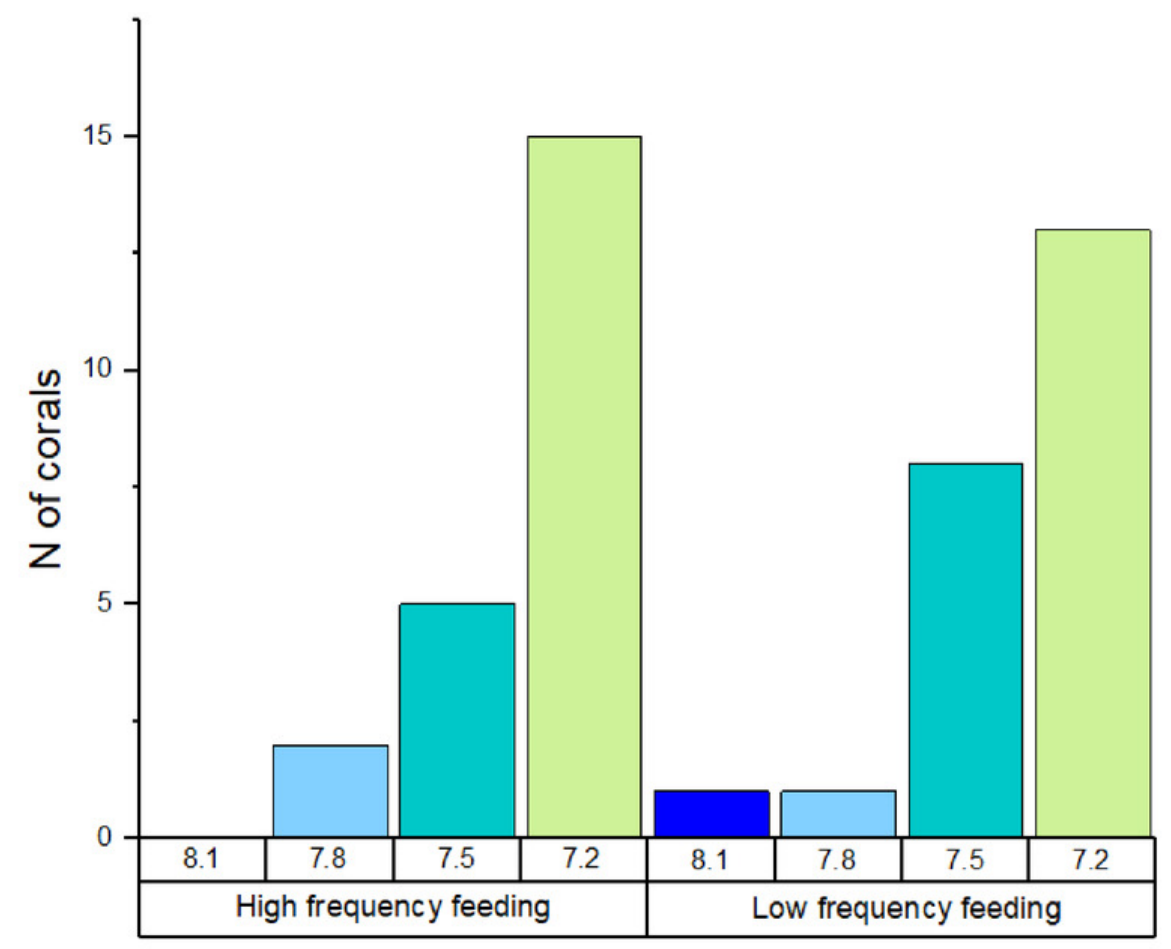




\section{Table $\mathbf{1}$ (on next page)}

Chemical and physical properties of seawater in the aquaria for each treatment (mean $\pm \mathrm{SD}$ ) during the experiment.

A) Measured temperature, salinity, $\mathrm{pH}$ and alkalinity (TA). B) Carbonate system in the aquaria: $p \mathrm{CO}_{2:}$ partial pressure of $\mathrm{CO}_{2} ; \chi \mathrm{CO}_{2}$ : molar fraction of $\mathrm{CO}_{2} ;\left[\mathrm{HCO}_{3}{ }^{-}\right]$: bicarbonate ion concentration; $\left[\mathrm{CO}_{3}^{2-}\right]$ : carbonate ion concentration; $\left[\mathrm{CO}_{2}\right]_{\mathrm{aq}}$ : concentration of dissolved $\mathrm{CO}_{2}$; $\Omega_{\mathrm{a}}$ : aragonite saturation state were calculated using the CO2SYS excel spreadsheet software (Pierrot, Lewis and Wallace, 2006) and the measured variables. 


\begin{tabular}{cccccc}
\multicolumn{2}{c}{$\begin{array}{c}\text { Measured } \\
\text { variables }\end{array}$} & $\begin{array}{c}\mathbf{T} \\
\left({ }^{\circ} \mathbf{C}\right)\end{array}$ & Sal & $\begin{array}{c}\mathbf{p H} \\
\text { (total scale) }\end{array}$ & $\begin{array}{c}\mathbf{T A} \\
(\boldsymbol{\mu E q} / \mathbf{k g})\end{array}$ \\
\cline { 2 - 6 } & 8.1 & $11.0 \pm 0.1$ & $37.9 \pm 0.15$ & $8.12 \pm 0.01$ & $2537 \pm 4$ \\
$\mathrm{HF}$ & 7.8 & $11.1 \pm 0.2$ & $37.9 \pm 0.15$ & $7.73 \pm 0.05$ & $2541 \pm 4$ \\
& 7.5 & $11.0 \pm 0.1$ & $37.9 \pm 0.15$ & $7.5 \pm 0.02$ & $2539 \pm 4$ \\
& 7.2 & $11.0 \pm 0.1$ & $37.9 \pm 0.15$ & $7.25 \pm 0.02$ & $2540 \pm 4$ \\
\hline \multirow{4}{*}{ LF } & 8.1 & $10.9 \pm 0.1$ & $37.9 \pm 0.15$ & $8.10 \pm 0.03$ & $2537 \pm 4$ \\
& 7.8 & $10.9 \pm 0.1$ & $37.9 \pm 0.15$ & $7.73 \pm 0.05$ & $2541 \pm 4$ \\
& 7.5 & $10.9 \pm 0.1$ & $37.9 \pm 0.15$ & $7.52 \pm 0.01$ & $2539 \pm 4$ \\
& 7.2 & $10.9 \pm 0.1$ & $37.9 \pm 0.15$ & $7.24 \pm 0.02$ & $2541 \pm 4$ \\
\hline
\end{tabular}

3 B

\begin{tabular}{|c|c|c|c|c|c|c|c|c|}
\hline \multicolumn{2}{|c|}{$\begin{array}{c}\text { Calculated } \\
\text { variables }\end{array}$} & $\begin{array}{l}p \mathrm{CO}_{2} \\
(\mu \mathrm{tm})\end{array}$ & $\begin{array}{l}\mathrm{XCO}_{2} \\
(\mathrm{ppm})\end{array}$ & $\begin{array}{c}\text { DIC } \\
(\mu \mathrm{mol} / \mathrm{kg})\end{array}$ & $\begin{array}{c}{\left[\mathrm{HCO}_{3}^{-}\right]} \\
(\mu \mathrm{mol} / \mathrm{kg})\end{array}$ & $\begin{array}{c}{\left[\mathrm{CO}_{3}^{2}{ }^{2}\right]} \\
(\mu \mathrm{mol} / \mathrm{kg})\end{array}$ & $\begin{array}{c}{\left[\mathrm{CO}_{2}\right]_{\mathrm{aq}}} \\
(\mu \mathrm{mol} / \mathrm{kg})\end{array}$ & $\Omega_{A}$ \\
\hline \multirow{4}{*}{$\mathrm{HF}$} & 8.1 & $360 \pm 10$ & $360 \pm 10$ & $2274 \pm 8$ & $2073 \pm 10$ & $187 \pm 3$ & $14.8 \pm 0.3$ & $2.79 \pm 0.04$ \\
\hline & 7.8 & $1030 \pm 140$ & $1040 \pm 140$ & $2453 \pm 21$ & $2322 \pm 24$ & $88 \pm 9$ & $42.6 \pm 5.2$ & $1.31 \pm 0.13$ \\
\hline & 7.5 & $1730 \pm 100$ & $1750 \pm 100$ & $2533 \pm 10$ & $2408 \pm 9$ & $53 \pm 3$ & $72.0 \pm 3.8$ & $0.79 \pm 0.04$ \\
\hline & 7.2 & $3180 \pm 190$ & $3220 \pm 190$ & $2628 \pm 9$ & $2465 \pm 4$ & $30 \pm 2$ & $132.4 \pm 7.4$ & $0.45 \pm 0.02$ \\
\hline \multirow{4}{*}{ LF } & 8.1 & $384 \pm 34$ & $389 \pm 35$ & $2287 \pm 16$ & $2092 \pm 23$ & $179 \pm 8$ & $16.0 \pm 1.2$ & $2.67 \pm 0.13$ \\
\hline & 7.8 & $1010 \pm 130$ & $1030 \pm 130$ & $2453 \pm 20$ & $2323 \pm 22$ & $88 \pm 8$ & $42.4 \pm 5.0$ & $1.31 \pm 0.12$ \\
\hline & 7.5 & $1616 \pm 37$ & $1637 \pm 37$ & $2525 \pm 6$ & $2403 \pm 5$ & $55 \pm 1$ & $67.5 \pm 1.3$ & $0.82 \pm 0.02$ \\
\hline & 7.2 & $3190 \pm 190$ & $3230 \pm 190$ & $2630 \pm 8$ & $2467 \pm 3$ & $30 \pm 2$ & $133.1 \pm 6.8$ & $0.44 \pm 0.02$ \\
\hline
\end{tabular}

4 


\section{Table 2 (on next page)}

Descriptive statistics of the skeletal growth by treatment for the whole experiment (433 days).

Mean calcification rate expressed as $\mathrm{mg} \mathrm{CaCO}_{3} \mathrm{~g}^{-1} \mathrm{~d}^{-1 .} \mathrm{N}=152$. 


\begin{tabular}{|c|c|c|c|c|c|c|c|c|c|c|c|c|c|}
\hline & \multirow[b]{2}{*}{$\mathrm{pH}$} & \multicolumn{10}{|c|}{ Calcification rate } & \multicolumn{2}{|c|}{ Dissolution } \\
\hline & & Maximum & Median & Mean & $\%$ & SD & SE & Minimum & Variance & Skewness & Kurtosis & $\mathbf{N}$ & $\%$ affected \\
\hline \multirow{4}{*}{ HF } & 8.1 & 1.448 & 0.139 & 0.309 & 0.031 & 0.39 & 0.0089 & -0.003 & 0.15 & 1.75 & 2.92 & 0 & 0 \\
\hline & 7.8 & 1.043 & 0.037 & 0.163 & 0.016 & 0.31 & 0.0072 & -0.410 & 0.10 & 1.23 & 2.61 & 2 & 11 \\
\hline & 7.5 & 1.136 & 0.185 & 0.305 & 0.033 & 0.40 & 0.0101 & -0.116 & 0.16 & 0.95 & -0.22 & 5 & 26 \\
\hline & 7.2 & 0.524 & -0.172 & -0.170 & -0.015 & 0.31 & 0.0067 & -0.845 & 0.10 & 0.19 & 0.71 & 15 & 79 \\
\hline \multirow{4}{*}{ LF } & 8.1 & 0.329 & 0.034 & 0.055 & 0.006 & 0.09 & 0.0021 & -0.035 & 0.01 & 2.34 & 4.98 & 1 & 5 \\
\hline & 7.8 & 0.678 & 0.070 & 0.105 & 0.011 & 0.15 & 0.0035 & -0.011 & 0.02 & 3.15 & 11.56 & 1 & 5 \\
\hline & 7.5 & 0.372 & -0.003 & 0.017 & 0.002 & 0.13 & 0.0031 & -0.171 & 0.02 & 1.05 & 1.42 & 8 & 42 \\
\hline & 7.2 & 0.154 & -0.270 & -0.320 & -0.032 & 0.31 & 0.0070 & -1.078 & 0.09 & -0.88 & 1.10 & 13 & 68 \\
\hline Tot & & & & & & & & & & & & 45 & 30 \\
\hline
\end{tabular}




\section{Table 3(on next page)}

Summary of model results.

The effect of experimental conditions on the calcification rate of Desmophyllum dianthus corals was tested taking as a reference the calcification rate at each sampling period (discrete measures T0-T3). Note that the number of values that are free to vary, known as degrees of freedom ( $n-1)$ in this model, refers then to $152-1$ corals per 3 discrete measurements. 
2 ANOVA

\begin{tabular}{lcccc} 
DF & \multicolumn{2}{c}{436} & & \\
Factors & DF & F-value & p-value & Significance \\
\cline { 2 - 5 }$\quad$ Intercept & 1 & 42.757 & $<0.0001$ & $* * *$ \\
$\quad$ pH & 3 & 88.325 & $<0.0001$ & $* * *$ \\
$\quad$ Feed & 1 & 26.548 & $<0.0001$ & $* * *$ \\
Weight class & 3 & 21.876 & $<0.0001$ & $* * *$ \\
$\quad$ Time & 2 & 2.800 & 0.0619 & $* * *$ \\
Residual standard error & 0.6751729 & & \\
Degrees of freedom: & 446 total & 436 residual &
\end{tabular}




\section{Table 4(on next page)}

Calcification rates between periods

Mean calcification rate expressed as $\mathrm{mg} \mathrm{CaCO}_{3} \mathrm{~g}^{-1} \mathrm{~d}^{-1}$, percentage mass increase and standard deviation by periods of measurement (discrete weight measurements T0-T3). $\mathrm{N}=152$. 


\begin{tabular}{ccccccccccc} 
& & \multicolumn{3}{c}{ T0-1 } & \multicolumn{3}{c}{ T1-2 } & \multicolumn{3}{c}{ T2-3 } \\
\cline { 2 - 11 } & pH & Mean & \% & SD & Mean & \% & SD & Mean & \% & SD \\
\hline \multirow{4}{*}{ HF } & 8.1 & 0.348 & 0.035 & 0.53 & 0.340 & 0.031 & 0.41 & 0.272 & 0.023 & 0.36 \\
& 7.8 & 0.237 & 0.024 & 0.63 & 0.136 & 0.012 & 0.25 & 0.142 & 0.013 & 0.33 \\
& 7.5 & 0.360 & 0.036 & 0.85 & 0.250 & 0.024 & 0.45 & 0.310 & 0.027 & 0.42 \\
& 7.2 & -0.279 & -0.028 & 0.30 & -0.266 & -0.028 & 0.30 & -0.063 & -0.008 & 0.44 \\
\hline \multirow{4}{*}{ LF } & 8.1 & 0.067 & 0.007 & 0.13 & 0.069 & 0.007 & 0.11 & 0.042 & 0.004 & 0.10 \\
& 7.8 & 0.124 & 0.012 & 0.35 & 0.048 & 0.005 & 0.06 & 0.128 & 0.012 & 0.14 \\
& 7.5 & 0.001 & 0.000 & 0.28 & 0.000 & 0.000 & 0.11 & 0.034 & 0.003 & 0.17 \\
& 7.2 & -0.400 & -0.040 & 0.52 & -0.391 & -0.041 & 0.27 & -0.241 & -0.029 & 0.36 \\
\hline
\end{tabular}




\section{Table 5 (on next page)}

Results of the post-hoc pair-wise comparisons on the estimated marginal means. 


\begin{tabular}{|c|c|c|c|c|c|}
\hline \multicolumn{6}{|c|}{ High Frequency Feeding } \\
\hline Contrast & Estimate & SE & df & t.ratio & p.value \\
\hline $7.2-7.5$ & -0.2371 & 0.0213 & 61.3 & -11.140 & $<.0001$ \\
\hline $7.2-7.8$ & -0.3331 & 0.0209 & 65.3 & -15.914 & $<.0001$ \\
\hline $7.2-8.1$ & -0.3206 & 0.0204 & 56.8 & -15.736 & $<.0001$ \\
\hline $7.5-7.8$ & -0.096 & 0.0127 & 42.9 & -7.563 & $<.0001$ \\
\hline $7.5-8.1$ & -0.0835 & 0.0108 & 26.2 & -7.718 & $<.0001$ \\
\hline $7.8-8.1$ & 0.0124 & 0.0112 & 72.8 & 1.116 & 0.6811 \\
\hline \multicolumn{6}{|c|}{ Low Frequency Feeding } \\
\hline Contrast & Estimate & SE & df & t.ratio & p.value \\
\hline $7.2-7.5$ & -0.2371 & 0.0213 & 61.3 & -11.140 & $<.0001$ \\
\hline $7.2-7.8$ & -0.3331 & 0.0209 & 65.3 & -15.914 & $<.0001$ \\
\hline $7.2-8.1$ & -0.3206 & 0.0204 & 56.8 & -15.736 & $<.0001$ \\
\hline 7.5-7.8 & -0.096 & 0.0127 & 42.9 & -7.563 & $<.0001$ \\
\hline 7.5-8.1 & -0.0835 & 0.0108 & 26.2 & -7.718 & $<.0001$ \\
\hline 7.8-8.1 & 0.0124 & 0.0112 & 72.8 & 1.116 & 0.6811 \\
\hline
\end{tabular}




\section{Table 6(on next page)}

Summary of recent studies of Ocean Acidification effects on cold-water coral species from the world oceans. 


\begin{tabular}{|c|c|c|c|c|c|c|c|c|c|}
\hline Species & Area & $\begin{array}{l}\text { Peer } \\
\text { Depth (m) }\end{array}$ & $\begin{array}{c}\text { Incubation } \\
\text { time }\end{array}$ & pH (total scale) & TA ( $\mu \mathrm{mol}$ kg-1) & $\begin{array}{c}\text { Manus } \\
\mathbf{\Omega}_{\mathbf{A}}\end{array}$ & $\begin{array}{l}\mathbf{p c o}_{\mathbf{2}} \text { (ppm) } \\
\end{array}$ & $\begin{array}{l}\text { ewed } \\
\text { calcification rate }\end{array}$ & Reference \\
\hline D. dianthus & Chilean Patagonia & $18-23$ & 14 months & $8.12 \pm 0.01$ & $2537 \pm 4$ & $2.79 \pm 0.04$ & $360 \pm 10$ & $0.309 \pm 0.39\left(\mathrm{mg} \mathrm{CaCO}_{3} \mathrm{~g}^{-1} \mathrm{~d}^{-1}\right)$ & This study \\
\hline D. dianthus & Chilean Patagonia & $18-23$ & 14 months & $7.73 \pm 0.05$ & $2541 \pm 4$ & $1.31 \pm 0.13$ & $1030 \pm 140$ & $0.163 \pm 0.31\left(\mathrm{mg} \mathrm{CaCO}_{3} \mathrm{~g}^{-1} \mathrm{~d}^{-1}\right)$ & This study \\
\hline D. dianthus & Chilean Patagonia & $18-23$ & 14 months & $7.5 \pm 0.02$ & $2539 \pm 4$ & $0.79 \pm 0.04$ & $1730 \pm 100$ & $0.305 \pm 0.30\left(\mathrm{mg} \mathrm{CaCO}_{3} \mathrm{~g}^{-1} \mathrm{~d}^{-1}\right)$ & This study \\
\hline D. dianthus & Chilean Patagonia & $18-23$ & 14 months & $7.25 \pm 0.02$ & $2540 \pm 4$ & $0.45 \pm 0.02$ & $3180 \pm 190$ & $-0.170 \pm 0.31\left(\mathrm{mg} \mathrm{CaCO}_{3} \mathrm{~g}^{-1} \mathrm{~d}^{-1}\right)$ & This study \\
\hline D. dianthus & Chilean Patagonia & $18-23$ & 14 months & $8.10 \pm 0.03$ & $2537 \pm 4$ & $2.67 \pm 0.13$ & $384 \pm 34$ & $0.055 \pm 0.99\left(\mathrm{mg} \mathrm{CaCO}_{3} \mathrm{~g}^{-1} \mathrm{~d}^{-1}\right)$ & This study \\
\hline D. dianthus & Chilean Patagonia & $18-23$ & 14 months & $7.73 \pm 0.05$ & $2541 \pm 4$ & $1.31 \pm 0.12$ & $1010 \pm 130$ & $0.105 \pm 0.15\left(\mathrm{mg} \mathrm{CaCO}_{3} \mathrm{~g}^{-1} \mathrm{~d}^{-1}\right)$ & This study \\
\hline D. dianthus & Chilean Patagonia & $18-23$ & 14 months & $7.52 \pm 0.01$ & $2539 \pm 4$ & $0.82 \pm 0.02$ & $1616 \pm 37$ & $0.017 \pm 0.13\left(\mathrm{mg} \mathrm{CaCO}_{3} \mathrm{~g}^{-1} \mathrm{~d}^{-1}\right)$ & This study \\
\hline D. dianthus & Chilean Patagonia & $18-23$ & 14 months & $7.24 \pm 0.02$ & $2541 \pm 4$ & $0.44 \pm 0.02$ & $3190 \pm 190$ & $-0.320 \pm 0.31\left(\mathrm{mg} \mathrm{CaCO}_{3} \mathrm{~g}^{-1} \mathrm{~d}^{-1}\right)$ & This study \\
\hline D. dianthus & Adriatic sea & 430 & 8 months & 7.96 & & & 380 & $1.3\left(\mu \mathrm{mol} \mathrm{CaCO} 3 \mathrm{~cm}^{-2} \mathrm{~d}^{-1}\right)$ & Gori et al.. 2016 \\
\hline D. dianthus & Adriatic sea & 430 & 8 months & 7.92 & & & 750 & $1.8\left(\mu \mathrm{mol} \mathrm{CaCO} 3 \mathrm{~cm}^{-2} \mathrm{~d}^{-1}\right)$ & Gori et al.. 2016 \\
\hline D. dianthus & Adriatic sea & 430 & 8 months & 7.97 & & & 380 & $0.5\left(\mu \mathrm{mol} \mathrm{CaCO} 3 \mathrm{~cm}^{-2} \mathrm{~d}^{-1}\right)$ & Gori et al.. 2016 \\
\hline D. dianthus & Adriatic sea & 430 & 8 months & 7.9 & & & 750 & $0.7\left(\mu \mathrm{mol} \mathrm{CaCO} 3 \mathrm{~cm}^{-2} \mathrm{~d}^{-1}\right)$ & Gori et al.. 2016 \\
\hline D. dianthus & NW Mediterranean & 250 & 11 months & 7.81 & $2543 \pm 11$ & 1.6 & $810 \pm 53$ & $0.6\left(\mathrm{mg} \mathrm{CaCO} \mathrm{g}^{-1} \mathrm{~d}^{-1}\right)$ & Movilla et al.. 2014 \\
\hline D. dianthus & E Mediterranean & 300 & 11 months & 7.81 & $2536 \pm 14$ & 1.6 & $810 \pm 53$ & $1.06\left(\mathrm{mg} \mathrm{CaCO} \mathrm{g}^{-1} \mathrm{~d}^{-1}\right)$ & Movilla et al.. 2014 \\
\hline D. dianthus & Chilean Patagonia & 20 & 2 weeks & & & & & $0.25 \pm 0.18\left(\% d^{-1}\right)$ & Jantzen et al., 2013a \\
\hline D. dianthus & Chilean Patagonia & 20 & 2 weeks & & & & & $0.09 \pm 0.08\left(\% d^{-1}\right)$ & Jantzen et al., 2013a \\
\hline D. dianthus & Azores. NE Atlantic & 450 & 8 months & 7.7 & $2389.8 \pm 20.4$ & 1.16 & 997 & $0.003 \pm 0.004\left(\% d^{-1}\right)$ & $\begin{array}{c}\text { Carreiro-Silva et al.. } \\
2014\end{array}$ \\
\hline D. dianthus & Mediterranean & 690 & 5 days & & & $1.8 \pm 0.2$ & $563 \pm 57$ & $0.011 \pm 0.007\left(\% \mathrm{~d}^{-1}\right)$ & Maier et al.. 2012 \\
\hline L. pertusa & California Margin & 300 & 7 weeks & $7.89 \pm 0.04$ & $2282 \pm 30$ & 1.5 & $580 \pm 8$ & $0.02 \pm 0.009\left(\% d^{-1}\right)$ & Gómez et al., 2018 \\
\hline L. pertusa & California Margin & 300 & 7 weeks & $7.62 \pm 0.06$ & $2305 \pm 66$ & 0.8 & $1159 \pm 34$ & $-0.010 \pm 0.014\left(\% d^{-1}\right)$ & Gómez et al., 2018 \\
\hline L. pertusa & Norway & $145-220$ & 6 months & $7.948 \pm 0.47$ & $1962.8 \pm 170.0$ & $1.37 \pm 0.19$ & $430 \pm 101$ & $0.006 \pm 0.004\left(\% d^{-1}\right)$ & Büscher et al., 2017 \\
\hline L. pertusa & Norway & $145-220$ & 6 months & $7.710 \pm 0.056$ & $2221.5 \pm 0.1$ & $0.93 \pm 0.14$ & $899 \pm 101$ & $0.001 \pm 0.003\left(\% d^{-1}\right)$ & Büscher et al., 2017 \\
\hline L. pertusa & Norway & $145-220$ & 6 months & $7.916 \pm 0.031$ & $1,885.10 \pm 112.8$ & $1.44 \pm 0.14$ & $448 \pm 37$ & $0.010 \pm 0.004\left(\% \mathrm{~d}^{-1}\right)$ & Büscher et al., 2017 \\
\hline L. pertusa & Norway & $145-220$ & 6 months & $7.903 \pm 0.052$ & $1603.7 .8 \pm 384.6$ & $1.16 \pm 0.40$ & $392 \pm 66$ & $0.017 \pm 0.006\left(\% d^{-1}\right)$ & Büscher et al., 2017 \\
\hline L. pertusa & Norway & $145-220$ & 6 months & $7.692 \pm 0.076$ & $1982.8 \pm 62.2$ & $0.93 \pm 0.19$ & $859 \pm 133$ & $0.007 \pm 0.006\left(\% \mathrm{~d}^{-1}\right)$ & Büscher et al., 2017 \\
\hline L. pertusa & Norway & $145-220$ & 6 months & $7.698 \pm 0.057$ & $1,888.20 \pm 207.3$ & $0.88 \pm 0.10$ & $804 \pm 172$ & $0.009 \pm 0.003\left(\% d^{-1}\right)$ & Büscher et al., 2017 \\
\hline L. pertusa & Norway & $70-155$ & 2 weeks & 7.9 & $2312 \pm 21$ & $1.38 \pm 0.08$ & $579 \pm 41$ & $0.067 \pm 0.016$ (\% day-1) & Georgian et al.. 2016 \\
\hline L. pertusa & Norway & $70-155$ & 2 weeks & 7.75 & $2312 \pm 29$ & $1.00 \pm 0.05$ & $845 \pm 61$ & $0.056 \pm 0.015$ (\% day-1) & Georgian et al.. 2016 \\
\hline L. pertusa & Norway & $70-155$ & 2 weeks & 7.6 & $2309 \pm 26$ & $0.74 \pm 0.07$ & $1208 \pm 132$ & $0.048 \pm 0.011$ (\% day-1) & Georgian et al.. 2016 \\
\hline
\end{tabular}




\begin{tabular}{|c|c|c|c|c|c|c|c|c|c|}
\hline L. pertusa & Gulf of Mexico & $450-500$ & 2 weeks & 7.9 & $2333 \pm 16$ & $1.51 \pm 0.10$ & $552 \pm 42$ & $0.036 \pm 0.007$ (\% day-1) & Georgian et al.. 2016 \\
\hline L. pertusa & Gulf of Mexico & $450-500$ & 2 weeks & 7.75 & $2334 \pm 17$ & $1.07 \pm 0.07$ & $831 \pm 54$ & $0.0176 \pm 0.012(\%$ day -1$)$ & Georgian et al.. 2016 \\
\hline L. pertusa & Gulf of Mexico & $450-500$ & 2 weeks & 7.6 & $2331 \pm 15$ & $0.80 \pm 0.05$ & $1165 \pm 76$ & $0.009 \pm 0.003(\%$ day -1$)$ & Georgian et al.. 2016 \\
\hline L. pertusa & Gulf of Mexico & $385-400$ & 10 months & $7.90 \pm 0.06$ & $2320 \pm 85$ & $1.47 \pm 0.17$ & & $0.011 \pm 0.004(\%$ day -1$)$ & Lunden et al., 2014 \\
\hline L. pertusa & Gulf of Mexico & $385-400$ & 10 months & $7.80 \pm 0.07$ & $2352 \pm 32$ & $1.18 \pm 0.18$ & & $0.01 \pm 0.003(\%$ day -1$)$ & Lunden et al., 2014 \\
\hline L. pertusa & Gulf of Mexico & $385-400$ & 10 months & $7.67 \pm 0.16$ & $2371 \pm 9$ & $0.97 \pm 0.40$ & & $-0.007 \pm 0.002(\%$ day -1$)$ & Lunden et al., 2014 \\
\hline L. pertusa & Gulf of Mexico & $390-550$ & 10 months & $7.90 \pm 0.08$ & $2316 \pm 23$ & $1.47 \pm 0.23$ & & $0.039 \pm 0.01(\%$ day -1$)$ & Lunden et al., 2014 \\
\hline L. pertusa & Gulf of Mexico & $390-550$ & 10 months & $7.78 \pm 0.04$ & $2340 \pm 66$ & $1.11 \pm 0.1$ & & $-0.01 \pm 0.004(\%$ day -1$)$ & Lunden et al., 2014 \\
\hline L. pertusa & Gulf of Mexico & $390-550$ & 10 months & $7.67 \pm 0.1$ & $2309 \pm 24$ & $0.92 \pm 0.23$ & & $-0.008 \pm 0.003(\%$ day -1$)$ & Lunden et al., 2014 \\
\hline L. pertusa & Mediterranean & 500 & 5 days & & & $2.5 \pm 0.1$ & $389 \pm 10$ & $0.033 \pm 0.011\left(\% \mathrm{~d}^{-1}\right)$ & Maier et al.. 2012 \\
\hline L. pertusa & Mediterranean & 500 & 5 days & & & $2.6 \pm 0$ & $378 \pm 4$ & $0.09 \pm 0.020\left(\% \mathrm{~d}^{-1}\right)$ & Maier et al.. 2012 \\
\hline L. pertusa & Mediterranean & 267 & 5 days & & & $2.1 \pm 0.4$ & $441 \pm 56$ & $0.034 \pm 0.013\left(\% \mathrm{~d}^{-1}\right)$ & Maier et al.. 2012 \\
\hline L. pertusa & Mediterranean & 500 & 5 days & & & $1.3 \pm 0.3$ & $614 \pm 72$ & $0.037 \pm 0.036\left(\% \mathrm{~d}^{-1}\right)$ & Maier et al.. 2012 \\
\hline L. pertusa & Mediterranean & 500 & 5 days & & & $1.5 \pm 0.8$ & $863 \pm 588$ & $0.068 \pm 0.068\left(\% \mathrm{~d}^{-1}\right)$ & Maier et al.. 2012 \\
\hline L. pertusa & NW Mediterranean & $260-500$ & 9 months & $8.10 \pm 0.02$ & $2483 \pm 54$ & 2.4 & 444 & $0.021 \pm 0.017\left(\% \mathrm{~d}^{-1}\right)$ & Maier et al.. 2013 \\
\hline L. pertusa & NW Mediterranean & $260-500$ & 9 months & $7.73 \pm 0.02$ & $2477 \pm 36$ & $1.3 \pm 0.08$ & $969 \pm 25$ & $0.021 \pm 0.037\left(\% \mathrm{~d}^{-1}\right)$ & Maier et al.. 2013 \\
\hline L. pertusa & North Sea & $109-150$ & $24 \mathrm{~h}$ & 7.91 & 2255 & 1.38 & 544 & $7.85\left(\mu \mathrm{mol} \mathrm{Kg}{ }^{-1} \mathrm{~h}^{-1}\right)$ & Maier et al.. 2009 \\
\hline L. pertusa & North Sea & $109-150$ & $24 \mathrm{~h}$ & 7.76 & 2203 & 0.97 & 791 & $7.72\left(\mu \mathrm{mol} \mathrm{Kg}{ }^{-1} \mathrm{~h}^{-1}\right)$ & Maier et al.. 2009 \\
\hline L. pertusa & Norway & $100-285$ & 6 months & 8.02 & $2392 \pm 46$ & 1.72 & $509 \pm 32$ & $0.0068 \pm 0.00324\left(\% \mathrm{~d}^{-1}\right)$ & $\begin{array}{c}\text { Form and Riebesell } \\
2012\end{array}$ \\
\hline L. pertusa & Norway & $100-286$ & 6 months & 7.96 & $2298 \pm 73$ & 1.36 & $604 \pm 105$ & $0.00178 \pm\left(\% d^{-1}\right)$ & $\begin{array}{c}\text { Form and Riebesell } \\
2012\end{array}$ \\
\hline L. pertusa & Norway & $100-287$ & 6 months & 7.82 & $2232 \pm 61$ & 1.03 & $778 \pm 112$ & $0.00073 \pm 0.0029\left(\% \mathrm{~d}^{-1}\right)$ & $\begin{array}{c}\text { Form and Riebesell } \\
2012\end{array}$ \\
\hline L. pertusa & Norway & $100-288$ & 6 months & 7.76 & $2349 \pm 79$ & 0.93 & $982 \pm 146$ & $0.00127 \pm\left(\% \mathrm{~d}^{-1}\right)$ & $\begin{array}{c}\text { Form and Riebesell } \\
2012\end{array}$ \\
\hline L. pertusa & North Atlantic & $141-167$ & 21 days & $7.77 \pm 0.01$ & $2141.6 \pm 1.2$ & 1.03 & 750 & $0.0438 \pm 1.6\left(\% \mathrm{~d}^{-1}\right)$ & Hennige et al.. 2014 \\
\hline M. oculata & Mediterranean & 434 & 10 weeks & & & 2.30 & 453 & $122.7-109.9\left(\mu \mathrm{mol} \mathrm{m}^{-2} \mathrm{~h}^{-1}\right)$ & Maier et al.. 2016 \\
\hline M. oculata & Mediterranean & 434 & 10 weeks & & & 1.00 & 805 & $121.7-110.9\left(\mu \mathrm{mol} \mathrm{m}{ }^{-2} \mathrm{~h}^{-1}\right)$ & Maier et al.. 2016 \\
\hline M. oculata & Mediterranean & 434 & 10 weeks & & & 0.63 & 1638 & $-12.8\left(\mu \mathrm{mol} \mathrm{m} \mathrm{m}^{-2} \mathrm{~h}^{-1}\right)$ & Maier et al.. 2016 \\
\hline M. oculata & NW Mediterranean & $260-500$ & 9 months & $8.10 \pm 0.02$ & $2525 \pm 7$ & $2.9 \pm 0.11$ & $380 \pm 12$ & $0.017 \pm 0.014\left(\% \mathrm{~d}^{-1}\right)$ & Maier et al.. 2013 \\
\hline M. oculata & NW Mediterranean & $260-500$ & 9 months & $7.74 \pm 0.02$ & $250 \pm 62$ & $1.4 \pm 0.06$ & $947 \pm 20$ & $0.038 \pm 0.057\left(\% \mathrm{~d}^{-1}\right)$ & Maier et al.. 2013 \\
\hline B. elegans & California & & 8 months & $8.02 \pm 0.02$ & & $2.1 \pm 0.05$ & $410 \pm 21$ & $10-50 \mathrm{mg}$ dry weight & Crook et al., 2013 \\
\hline
\end{tabular}




\section{PeerJ}

\begin{tabular}{|c|c|c|c|c|c|c|c|}
\hline B. elegans & California & 8 months & $7.78 \pm 0.03$ & $1.3 \pm 0.1$ & $770 \pm 75$ & $5-38 \mathrm{mg}$ dry weight & Crook et al., 2013 \\
\hline B. elegans & California & 8 months & $7.59 \pm 0.02$ & $0.9 \pm 0.04$ & $1220 \pm 80$ & 5-40 mg dry weight & Crook et al., 2013 \\
\hline
\end{tabular}

